\title{
Measurement of interferences associated with the detection of the hydroperoxy radical in the atmosphere using laser-induced fluorescence
}

\author{
Michelle M. Lew ${ }^{1}$, Sebastien Dusanter ${ }^{2,3}$, and Philip S. Stevens ${ }^{1,3}$ \\ ${ }^{1}$ Department of Chemistry, Indiana University, Bloomington, IN, USA \\ ${ }^{2}$ IMT Lille Douai, Univ. Lille, SAGE - Département Sciences de l'Atmosphère et Génie de l'Environnement, \\ 59000 Lille, France \\ ${ }^{3}$ School of Public and Environmental Affairs, Indiana University, Bloomington, IN, USA
}

Correspondence: Philip S. Stevens (pstevens@indiana.edu)

Received: 17 June 2017 - Discussion started: 9 August 2017

Revised: 21 November 2017 - Accepted: 23 November 2017 - Published: 10 January 2018

\begin{abstract}
One technique used to measure concentrations of the hydroperoxy radical $\left(\mathrm{HO}_{2}\right)$ in the atmosphere involves chemically converting it to $\mathrm{OH}$ by addition of $\mathrm{NO}$ and subsequent detection of $\mathrm{OH}$. However, some organic peroxy radicals $\left(\mathrm{RO}_{2}\right)$ can also be rapidly converted to $\mathrm{HO}_{2}$ (and subsequently $\mathrm{OH}$ ) in the presence of $\mathrm{NO}$, interfering with measurements of ambient $\mathrm{HO}_{2}$ radical concentrations. This interference must be characterized for each instrument to determine to what extent various $\mathrm{RO}_{2}$ radicals interfere with measurements of $\mathrm{HO}_{2}$ and to assess the impact of this interference on past measurements. The efficiency of $\mathrm{RO}_{2}$-to- $\mathrm{HO}_{2}$ conversion for the Indiana University laser-induced fluorescencefluorescence assay by gas expansion (IU-FAGE) instrument was measured for a variety of $\mathrm{RO}_{2}$ radicals. Known quantities of $\mathrm{OH}$ and $\mathrm{HO}_{2}$ radicals were produced from the photolysis of water vapor at $184.9 \mathrm{~nm}$, and $\mathrm{RO}_{2}$ radicals were produced by the reaction of several volatile organic compounds (VOCs) with $\mathrm{OH}$. The conversion efficiency of $\mathrm{RO}_{2}$ radicals to $\mathrm{HO}_{2}$ was measured when $\mathrm{NO}$ was added to the sampling cell for conditions employed during several previous field campaigns. For these conditions, approximately $80 \%$ of alkene-derived $\mathrm{RO}_{2}$ radicals and $20 \%$ of alkane-derived $\mathrm{RO}_{2}$ radicals were converted to $\mathrm{HO}_{2}$. Based on these measurements, interferences from various $\mathrm{RO}_{2}$ radicals contributed to approximately $35 \%$ of the measured $\mathrm{HO}_{2}$ signal during the Mexico City Metropolitan Area (MCMA) 2006 campaign (MCMA-2006), where the measured VOCs consisted of a mixture of saturated and unsaturated species. However, this interference can contribute more significantly to the mea-
\end{abstract}

sured $\mathrm{HO}_{2}$ signal in forested environments dominated by unsaturated biogenic emissions such as isoprene.

\section{Introduction}

The hydroxyl radical $(\mathrm{OH})$ is one of the primary oxidants in the atmosphere (Levy, 1972). The reaction of OH radicals with volatile organic compounds (VOCs) leads to the production of peroxy radicals, both the hydroperoxy radical $\left(\mathrm{HO}_{2}\right)$ and organic peroxy radicals $\left(\mathrm{RO}_{2}\right)$, which in the presence of nitrogen oxides $\left(\mathrm{NO}_{x}=\mathrm{NO}+\mathrm{NO}_{2}\right)$ can lead to the production of ozone and secondary organic aerosols in the atmosphere. As a consequence, the development of effective control strategies for the formation of these pollutants requires an accurate understanding of the $\mathrm{OH}, \mathrm{HO}_{2}$, and $\mathrm{RO}_{2}$ radical chemistry in the atmosphere. Measurements of $\mathrm{OH}$ and $\mathrm{HO}_{2}$ (together $\mathrm{HO}_{x}$ ) can provide a robust test of our understanding of this complex oxidation chemistry.

Multiple field campaigns have been conducted over the years measuring $\mathrm{OH}$ and $\mathrm{HO}_{2}$ radicals in both urban and forested environments. While much attention has been focused on discrepancies between measured and modeled $\mathrm{OH}$ concentrations (Rohrer et al., 2014), the agreement between measured and modeled $\mathrm{HO}_{2}$ concentrations has been highly variable. In urban environments, measured $\mathrm{HO}_{2}$ concentrations were sometimes found to agree with model predictions (Shirley et al., 2006; Emmerson et al., 2007; Dusanter et al., 
2009b; Michoud et al., 2012; Lu et al., 2013; Ren et al., 2013; Griffith et al., 2016), while other times the measurements were found to be both lower (George et al., 1999; Konrad et al., 2003) and higher than model predictions (Martinez et al., 2003; Ren et al., 2003; Emmerson et al., 2005; Kanaya et al., 2007a; Chen et al., 2010; Sheehy et al., 2010; Czader et al., 2013; Griffith et al., 2016). In forested environments, measured $\mathrm{HO}_{2}$ concentrations were sometimes found to agree with model predictions (Tan et al., 2001; Ren et al., 2005, 2006) but were often found to be either lower (Carslaw et al., 2001; Kanaya et al., 2007b, 2012; Whalley et al., 2011; Mao et al., 2012; Griffith et al., 2013) or higher than model predictions (Carslaw et al., 2001; Kubistin et al., 2010; Kim et al., 2013; Hens et al., 2014).

These results question our understanding of $\mathrm{HO}_{x}$ radical chemistry and the ability of models to simulate future changes in the chemical composition of the atmosphere. However, a recent intercomparison of several instruments measuring $\mathrm{HO}_{2}$ found that the agreement between the different instruments was variable, although the measurements were highly correlated (Fuchs et al., 2010). While the differences were within the combined uncertainties of the measurements, there were several measurement periods when the differences could not be explained by instrumental uncertainties. These results suggested the possibility of potential interferences in the $\mathrm{HO}_{2}$ measurement technique.

Laser-induced fluorescence using the fluorescence assay by gas expansion technique (LIF-FAGE) is a common method for measuring $\mathrm{HO}_{2}$ radicals in the atmosphere. In this technique $\mathrm{HO}_{2}$ radicals are measured indirectly after sampling ambient air at low pressure through chemical conversion to $\mathrm{OH}$ by addition of $\mathrm{NO}$ as shown in Reaction (R1) and subsequent detection of $\mathrm{OH}$ by LIF:

$\mathrm{HO}_{2}+\mathrm{NO} \rightarrow \mathrm{OH}+\mathrm{NO}_{2}$.

It was previously believed that the detection of $\mathrm{HO}_{2}$ radicals using the LIF-FAGE technique was free from interferences from the reaction of $\mathrm{RO}_{2}$ radicals with $\mathrm{NO}$, as model simulations and measurements suggested that the rate of conversion of $\mathrm{RO}_{2}$ radicals to $\mathrm{HO}_{2}$ by Reactions (R2) and (R3) and subsequent conversion to $\mathrm{OH}$ through Reaction (R1) was negligible due to the slow rate of Reaction (R3) under the reduced oxygen concentration in the low-pressure LIF-FAGE cell and the short reaction time between injection of $\mathrm{NO}$ and detection of $\mathrm{OH}$ (Heard and Pilling, 2003).

$\mathrm{RO}_{2}+\mathrm{NO} \rightarrow \mathrm{RO}+\mathrm{NO}_{2}$

$\mathrm{RO}+\mathrm{O}_{2} \rightarrow \mathrm{R}^{\prime} \mathrm{O}+\mathrm{HO}_{2}$

For example, $\mathrm{RO}_{2}$ radicals produced from the $\mathrm{OH}$-initiated oxidation of small alkanes were found to produce a negligible yield of $\mathrm{HO}_{2}$ (Stevens et al., 1994; Kanaya et al., 2001; Tan et al., 2001; Creasey et al., 2002; Holland et al., 2003).

However, recent laboratory studies have shown that there are interferences associated with measurements of $\mathrm{HO}_{2}$ us- ing this technique from the conversion of $\mathrm{RO}_{2}$ radicals derived from the $\mathrm{OH}$-initiated oxidation of alkenes and aromatics to $\mathrm{HO}_{2}$ (and subsequently $\mathrm{OH}$ ) by reaction with NO. Measured $\mathrm{RO}_{2}$-to- $\mathrm{HO}_{2}$ conversion efficiencies of $95 \%$ for the peroxy radicals derived from the $\mathrm{OH}$-initiated oxidation of propene and $86 \%$ for the peroxy radicals derived from the $\mathrm{OH}$-initiated oxidation of benzene have been reported (Fuchs et al., 2011). The high conversion efficiency of alkene-based peroxy radicals to $\mathrm{HO}_{2}$ is due to the ability of the $\beta$-hydroxyalkoxy radicals produced from Reaction (R2) to rapidly decompose, forming a hydroxyalkyl radical which then reacts rapidly with $\mathrm{O}_{2}$ and leads to the production of a carbonyl compound and $\mathrm{HO}_{2}$ (Fuchs et al., 2011; Whalley et al., 2013). The conversion efficiency depends on the instrumental characteristics and the configurations employed (Fuchs et al., 2011; Whalley et al., 2013). As a result, this interference must be characterized for all LIF-FAGE instruments for the accurate analysis of ambient $\mathrm{HO}_{2}$.

This paper will describe the characterization of the $\mathrm{RO}_{2}$ interferences associated with the Indiana University LIFFAGE instrument under several past campaign configurations. These include the Mexico City Metropolitan Area (MCMA) campaign in 2006 (MCMA-2006; Dusanter et al., 2009a, b), the Community Atmosphere-Biosphere INteractions EXperiments (CABINEX) in 2009 (Griffith et al., 2013), and the California Research at the Nexus of Air Quality and Climate Change campaign in Los Angeles (CalNex) in 2010 (Griffith et al., 2016). The impact of this interference on the previously published results from the MCMA 2006 campaign and a reanalysis of these $\mathrm{HO}_{2}$ measurements will be discussed.

\section{Experimental section}

\subsection{Instrument description}

The Indiana University LIF-FAGE instrument (IU-FAGE) has been described in detail previously (Dusanter et al., 2008, 2009a; Griffith et al., 2013, 2016). In the LIF-FAGE technique, $\mathrm{OH}$ radicals are detected by laser-induced fluorescence after expansion of ambient air to low pressure. This enhances the $\mathrm{OH}$ fluorescence lifetime, allowing temporal filtering of the fluorescence from laser scatter (Heard and Pilling, 2003). A diagram of the IU-FAGE detection cell is illustrated in Fig. 1. Ambient air is expanded through an orifice between 0.635 and $1.016 \mathrm{~mm}$ diameter located at the top of a cylindrical nozzle $(5 \mathrm{~cm}$ in diameter and $20 \mathrm{~cm}$ long). The size of the orifice was kept unchanged during each campaign but was varied between the different campaigns reported here. Two scroll pumps (Edwards XDS 35i) connected in parallel maintain a pressure inside the cell between 4 and 7.5 Torr depending on the sampling size of the orifice and the pumping speed, resulting in a flow rate between 3 and 10 SLPM through the sampling nozzle. 


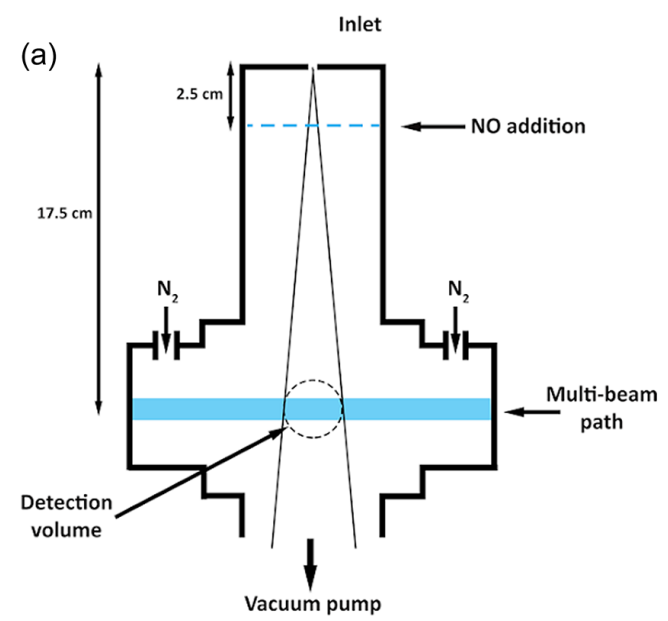

(b)

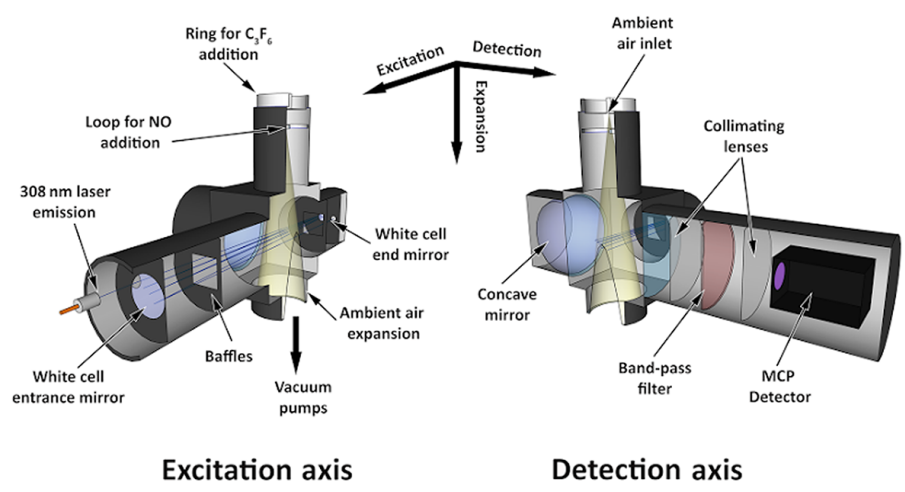

Figure 1. Indiana University LIF-FAGE cross section (a) and a schematic of the excitation axis and the detection axis (b; Dusanter et al., 2008).

The original IU-FAGE laser system used in this study and in the MCMA 2006 campaign consisted of a Spectra-Physics Navigator II YHP40-532Q diode-pumped Nd:YAG laser that produced approximately $5.5 \mathrm{~W}$ of radiation at $532 \mathrm{~nm}$ at a repetition rate of $5 \mathrm{kHz}$. This laser pumped a Lambda Physik Scanmate 1 dye laser (Rhodamine $640,0.25 \mathrm{~g} \mathrm{~L}^{-1}$ in isopropanol) that produced tunable radiation around $616 \mathrm{~nm}$, which was frequency doubled to generate 2 to $20 \mathrm{~mW}$ of radiation at $308 \mathrm{~nm}(\sim 20 \mathrm{~ns}$ pulse width). This laser system was recently replaced with a Spectra-Physics Navigator II YHP40-532Q that produces approximately $8 \mathrm{~W}$ of radiation at $532 \mathrm{~nm}$ at a repetition rate of $10 \mathrm{kHz}$ that pumps a Sirah Credo Dye laser $\left(255 \mathrm{mg} \mathrm{L}^{-1}\right.$ of Rhodamine 610 and $80 \mathrm{mg} \mathrm{L}^{-1}$ of Rhodamine 101 in ethanol), resulting in 40 to $100 \mathrm{~mW}$ of radiation at $308 \mathrm{~nm}$. Measurements of the conversion efficiencies were similar for the two laser systems. After exiting the dye laser, the beam was focused onto the entrance of a $12 \mathrm{~m}$ optical fiber to transmit the radiation to the sampling cell. In the detection cell, the laser crosses the expanded air perpendicular to the flow in a White cell configuration with approximately 24 passes.

$\mathrm{OH}$ radicals are excited using the $A^{2} \Sigma^{+} v^{\prime}=0 \leftarrow$ $X^{2} \Pi v^{\prime \prime}=0$ transition near $308 \mathrm{~nm}$ (Stevens et al., 1994). The net signal is measured by turning the wavelength on and off resonance in successive modulation cycles. A reference cell where $\mathrm{OH}$ is produced by thermal dissociation of water vapor is used to ensure that the laser is tuned on and off the $\mathrm{OH}$ transition. The $\mathrm{OH}$ fluorescence is detected using a microchannel plate photomultiplier tube (MCP-PMT) detector (Hamamatsu R5946U-50), a preamplifier (Stanford Research System SR445), and a gated photon counter (Stanford Research Systems SR400). The MCP-PMT is switched off during the laser pulse through the use of electronic gating allowing the $\mathrm{OH}$ fluorescence to be temporally filtered from laser scattered light.
A Teflon injector located approximately $2.5 \mathrm{~cm}$ below the inlet and $17.5 \mathrm{~cm}$ above the detection axis (Fig. 1) allowed for the addition of NO (Matheson, 99.8\%) to convert ambient $\mathrm{HO}_{2}$ to $\mathrm{OH}$ through Reaction (R1). The fraction of $\mathrm{HO}_{2}\left(C_{\mathrm{HO}_{2}}\right)$ converted into $\mathrm{OH}$ was measured during calibration experiments (Dusanter et al., 2008). The NO flow (approximately 1-3 $\times 10^{13} \mathrm{~cm}^{-3}$ ) maximized the conversion of $\mathrm{HO}_{2}$ into $\mathrm{OH}$ while minimizing the removal of $\mathrm{OH}$ by the $\mathrm{OH}+\mathrm{NO}$ reaction.

\subsection{Instrument calibration for $\mathrm{OH}$ and $\mathrm{HO}_{2}$}

The IU-FAGE instrument is calibrated by producing known quantities of $\mathrm{OH}$ and $\mathrm{HO}_{2}$ radicals from the photolysis of water vapor in air (Reactions R4 and R5; Dusanter et al., 2008):

$\mathrm{H}_{2} \mathrm{O}+\mathrm{hv}(184.9 \mathrm{~nm}) \rightarrow \mathrm{H}+\mathrm{OH}$,

$\mathrm{H}+\mathrm{O}_{2} \rightarrow \mathrm{HO}_{2}$.

The calibration source consists of an aluminum flow reactor $(1.27 \times 1.27 \times 30 \mathrm{~cm})$ equipped with quartz windows on two sides (Fig. 2). The light source consists of a low-pressure mercury pen lamp (UVP, LLC) housed in an aluminum cartridge that is continuously purged with dry nitrogen to prevent light absorption by gases in addition to helping to stabilize the lamp temperature. The radiation from the lamp passes through a band-pass filter centered at $185 \mathrm{~nm}$ (Acton Research) prior to entering the reactor and is detected by a photodiode. The lamp housing can be adjusted along the length of the calibrator to measure the loss of radicals between the source region and the exit of the calibrator.

The concentration of $\mathrm{OH}$ and $\mathrm{HO}_{2}$ radicals produced by the calibration source can be determined from the following equation:

$[\mathrm{OH}]=\left[\mathrm{HO}_{2}\right]=\left[\mathrm{H}_{2} \mathrm{O}\right] \cdot \sigma_{\mathrm{H}_{2} O} \cdot \varphi_{\mathrm{OH}+\mathrm{H}} \cdot F \cdot t$. 


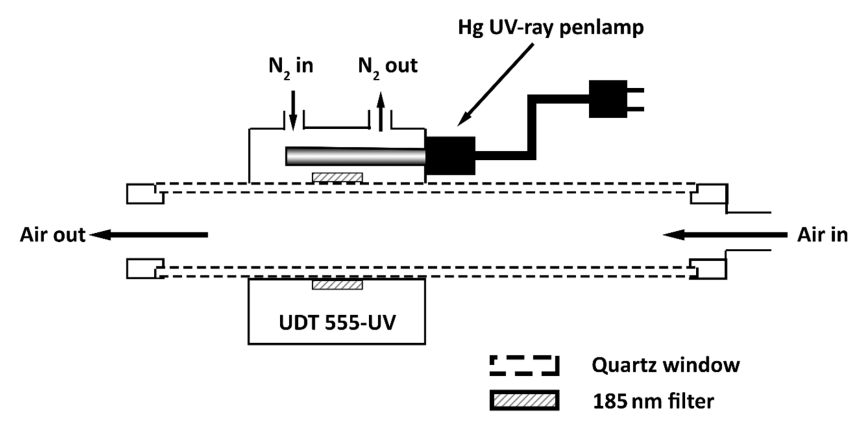

Figure 2. Cross section of Indiana University calibration source for the IU-FAGE instrument.

In this equation, $\phi_{\mathrm{OH}+\mathrm{H}}$ is the quantum yield of $\mathrm{OH}$ from water photolysis and $\sigma_{\mathrm{H}_{2} \mathrm{O}}$ is the absorption cross section of water $\left(7.14 \times 10^{-20} \mathrm{~cm}^{-2}\right.$ molecule ${ }^{-1}$; Cantrell et al., 1997; Hofzumahaus et al., 1997; Creasey et al., 2000). The product of the photon flux $(F)$ and the photolysis time $(t)$ can be determined from oxygen actinometry, as the photolysis of oxygen at $185 \mathrm{~nm}$ leads to the production of ozone (Reactions R6 and R7; Okabe, 1978):

$\mathrm{O}_{2}+\mathrm{hv}(184.9 \mathrm{~nm}) \rightarrow 2 \mathrm{O}\left({ }^{3} \mathrm{P}\right)$,

$\mathrm{O}_{2}+\mathrm{O}\left({ }^{3} \mathrm{P}\right)+\mathrm{M} \rightarrow \mathrm{O}_{3}+\mathrm{M}$

The concentration of $\mathrm{HO}_{x}$ radicals can thus be calculated from measured concentrations of water and ozone using Eq. (2) (Heard and Pilling, 2003; Holland et al., 2003):

$[\mathrm{OH}]=\left[\mathrm{HO}_{2}\right]=\left[\mathrm{H}_{2} \mathrm{O}\right] \cdot \sigma_{\mathrm{H}_{2} \mathrm{O}} \cdot \varphi_{\mathrm{OH}+\mathrm{H}} \cdot \frac{\left[\mathrm{O}_{3}\right]}{\varphi_{\mathrm{O}_{3}} \cdot \sigma_{\mathrm{O}_{2}} \cdot\left[\mathrm{O}_{2}\right]}$.

Here $\phi_{\mathrm{O}_{3}}$ is the quantum yield of $\mathrm{O}_{3}$ from oxygen photolysis and $\sigma_{\mathrm{O}_{2}}$ is the absorption cross sections of $\mathrm{O}_{2}$, which must be experimentally determined for each pen lamp due to the overlap of the highly structured absorption spectrum of $\mathrm{O}_{2}$ and the lineshape of the emission at $184.9 \mathrm{~nm}$. The lineshape depends on the operating conditions of the lamp as a result of line reversal and potential fluorescence of the fused silica envelope (Cantrell et al., 1997; Hofzumahaus et al., 1997; Lanzendorf et al., 1997).

\subsection{Measurement of the $\mathrm{RO}_{2}$ conversion efficiency to $\mathrm{HO}_{2}$}

Various alkenes (isoprene; methyl vinyl ketone, MVK; methacrolein, MACR; methyl ethyl ketone, MEK; ethene; trans-2-butene; tetramethylethylene, TME), alkanes (propane, butane, octane), and aromatic compounds (toluene) were used to measure the conversion efficiency of $\mathrm{RO}_{2}$ radicals to $\mathrm{HO}_{2}$. These VOCs were added to the main calibrator flow, either by direct addition of a gas mixture or by bubbling air through the liquid compound (Tables S1 and S2 in the Supplement), approximately $190 \mathrm{~ms}$ prior to the radical source to ensure that the added VOC was well mixed into the humid air flow before photolysis within the calibration source. The concentration of each VOC added to the calibrator was increased to react and remove the majority of the $\mathrm{OH}$ produced in the calibrator, resulting in $\mathrm{RO}_{2}$ concentrations that were approximately equal to the concentration of $\mathrm{OH}$ reacted away. These $\mathrm{RO}_{2}$ radicals are then sampled into the IU-FAGE instrument. Addition of $\mathrm{NO}$ inside the detection axis converts a fraction of the $\mathrm{RO}_{2}$ radicals to $\mathrm{HO}_{2}$ through Reactions (R2) and (R3). Since $\mathrm{RO}_{2}$ is produced together with $\mathrm{HO}_{2}$ in the calibrator, there is a subsequent conversion of both $\mathrm{RO}_{2}$ and $\mathrm{HO}_{2}$ into $\mathrm{OH}$ in the IU-FAGE cell, which is then detected by LIF.

Figure 3 illustrates two typical experiments designed to measure the conversion efficiency of $\mathrm{RO}_{2}$ radicals to $\mathrm{HO}_{2}$ in the IU-FAGE instrument. The total $\mathrm{HO}_{x}$ signal is defined as the sum of the total $\mathrm{OH}\left(S_{\mathrm{OH}}\right)$ and $\mathrm{HO}_{2}\left(S_{\mathrm{HO}_{2}}\right)$ produced by the mercury pen lamp in the absence of the added VOC (Eq. 3):

$S_{\mathrm{HO}_{x}}=S_{\mathrm{HO}_{2}}+S_{\mathrm{OH}}$

The $\mathrm{OH}$ concentration produced by the pen lamp is measured at the beginning, middle, and at the end of each experiment to ensure that the concentrations remained stable (experimental mode 1 in Fig. 3). Once the $\mathrm{OH}$ signal $\left(S_{\mathrm{OH}}\right)$ stabilizes, $\mathrm{NO}$ is added internally to the detection cell to convert $\mathrm{HO}_{2}$ into $\mathrm{OH}$ and measure the total $\mathrm{HO}_{x}$ signal $\left(\mathrm{S}_{\mathrm{HO}_{x}}\right.$; mode 2 in Fig. 3). The conversion efficiency of $\mathrm{HO}_{2}$ to $\mathrm{OH}$ is defined by Eq. (4):

$C_{\mathrm{HO}_{2} \rightarrow \mathrm{OH}}=\frac{S_{\mathrm{HO}_{x}}-S_{\mathrm{OH}}}{S_{\mathrm{OH}_{0}}}=\frac{S_{\mathrm{HO}_{2}}}{S_{\mathrm{OH}_{0}}}$.

$\mathrm{S}_{\mathrm{OH}_{0}}$ is the $\mathrm{OH}$ signal after accounting for the loss of $\mathrm{OH}$ on the walls of the calibrator (approximately $20 \%$ ). The wall loss for $\mathrm{HO}_{2}$ is negligible in the calibrator (Dusanter et al., 2008).

Next, internal $\mathrm{NO}$ addition is stopped and the $\mathrm{OH}$ signal is measured again to ensure the stability of radical production during the experiment. The VOC is then added to the calibration system, resulting in a decrease in the observed $\mathrm{OH}$ signal (mode 3 in Fig. 3). The remaining $\mathrm{OH}$ signal in the presence of the VOC is denoted as $S_{\mathrm{OH}+\mathrm{VOC}}$. For alkenes such as isoprene, the fast reaction with $\mathrm{OH}$ results in an almost total removal of $\mathrm{OH}$ radicals from the calibration source and $\mathrm{S}_{\mathrm{OH}+\mathrm{VOC}}$ is close to zero. However, for less reactive alkanes such as butane, the added VOC concentration was often not sufficient to completely remove $\mathrm{OH}$ radicals due to the short reaction time in the calibrator, resulting in a nonzero $\mathrm{S}_{\mathrm{OH}+\mathrm{VOC}}$ signal. The conversion efficiency in which OH radicals are converted to $\mathrm{RO}_{2}$ radicals $\left(\mathrm{COH}_{\mathrm{OHO}}\right)$ is defined by Eq. (5), which is derived from integrating the expressions for the rate of $\mathrm{OH}$ loss and the rate of $\mathrm{RO}_{2}$ production from the 

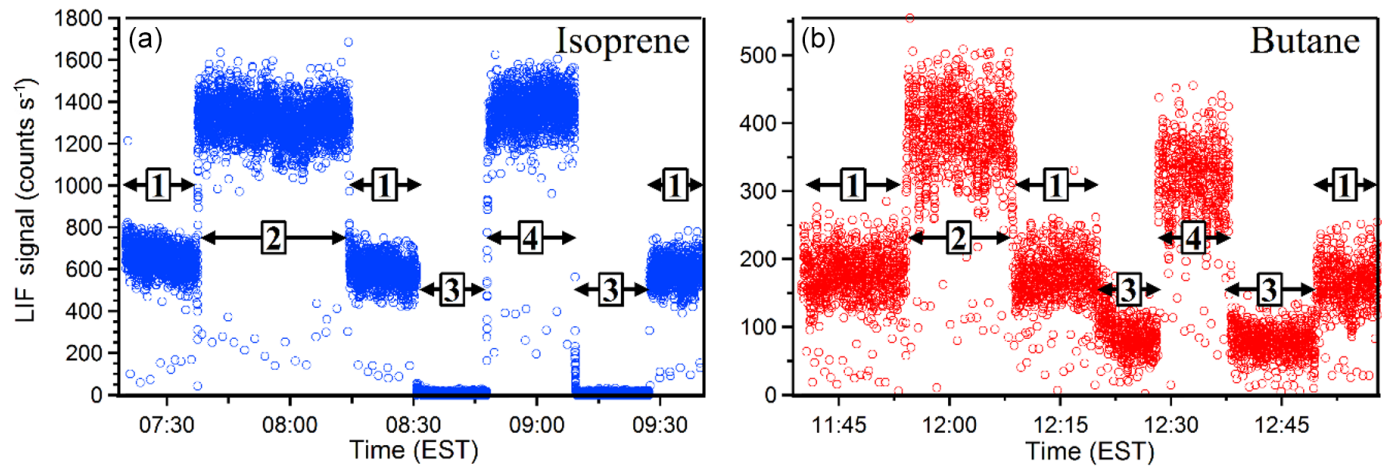

Figure 3. $\mathrm{RO}_{2}$ interference measurement experiment for isoprene (a; with an $\mathrm{OH}$ reactivity of approximately $\left.290 \mathrm{~s}^{-1}\right)$ and butane $(\mathbf{b}$; with an $\mathrm{OH}$ reactivity of approximately $30 \mathrm{~s}^{-1}$ ). The boxed numbers within the figure represent the various experimental modes: (1) $S_{\mathrm{OH}}$, (2) $S_{\mathrm{HO}}$ with internal NO addition, (3) $S_{\mathrm{OH}}+$ VOC with VOC added, and (4) $S_{\mathrm{RO}_{x}}$ with VOC added and internal NO addition.

$\mathrm{OH}+\mathrm{VOC}$ reaction:

$C_{\mathrm{OH} \rightarrow \mathrm{RO}_{2}}=\frac{\left[\mathrm{RO}_{2}\right]}{[\mathrm{OH}]_{0}}=\frac{F_{\mathrm{OH}}-k_{\mathrm{w}} t}{F_{\mathrm{OH}}}\left(1-e^{-F_{\mathrm{OH}}}\right)$

$F_{\mathrm{OH}}=\ln \left(\frac{S_{\mathrm{OH}_{0}}}{S_{\mathrm{OH}+\mathrm{VOC}}}\right)$,

where $k_{\mathrm{w}} t$ is the product of the rate constant for the reaction of $\mathrm{OH}$ radicals on the wall of the calibration source with the reaction time $t$, reflecting the measured loss of $\mathrm{OH}$ on the walls of the calibrator (Dusanter et al., 2008).

The subsequent addition of $\mathrm{NO}$ to the detection cell will convert a fraction of $\mathrm{RO}_{2}$ radicals and $\mathrm{HO}_{2}$ radicals to $\mathrm{OH}$ (mode 4 in Fig. 3). The conversion efficiency of $\mathrm{RO}_{2}$ to $\mathrm{OH}$ $\left(C_{\mathrm{RO}_{2} \rightarrow \mathrm{OH}}\right)$ is determined by multiplying the fraction of $\mathrm{RO}_{2}$ radicals converted to $\mathrm{HO}_{2}\left(f_{\mathrm{RO}_{2} \rightarrow \mathrm{HO}_{2}}\right)$ with the conversion efficiency of $\mathrm{HO}_{2}$ to $\mathrm{OH}\left(C_{\mathrm{HO}_{2} \rightarrow \mathrm{OH}}\right)$ :

$C_{\mathrm{RO}_{2} \rightarrow \mathrm{OH}}=f_{\mathrm{RO}_{2} \rightarrow \mathrm{HO}_{2}} \cdot C_{\mathrm{HO}_{2} \rightarrow \mathrm{OH}}$.

The signal due to $\mathrm{RO}_{2}$ radicals $\left(S_{\mathrm{RO}_{2}}\right)$ is defined as the original $\mathrm{OH}$ signal $\left(\mathrm{S}_{\mathrm{OH}_{0}}\right)$ multiplied by the conversion efficiency of $\mathrm{OH}$ radicals to $\mathrm{RO}_{2}$ radicals $\left(C_{\mathrm{OH} \rightarrow \mathrm{RO}_{2}}\right)$ and multiplied by the conversion efficiency of $\mathrm{RO}_{2}$ to $\mathrm{OH}\left(C_{\mathrm{RO}_{2} \rightarrow \mathrm{OH}}\right.$; Eq. 7):

$S_{\mathrm{RO}_{2}}=S_{\mathrm{OH}_{0}} \cdot C_{\mathrm{OH} \rightarrow \mathrm{RO}_{2}} \cdot C_{\mathrm{RO}_{2} \rightarrow \mathrm{OH}}$.

For $\mathrm{OH}+\mathrm{VOC}$ reactions that lead to the production of $\mathrm{HO}_{2}$ with a yield of $y(\mathrm{OH}+$ benzene and toluene for example; Klotz et al., 1998; Nehr et al., 2011), the $\mathrm{OH}$ to $\mathrm{RO}_{2}$ conversion efficiency $\left(C_{\mathrm{OH}+\mathrm{VOC}}\right)$ must be multiplied by the overall yield $(1-y)$ of $\mathrm{RO}_{2}$ radicals produced from the $\mathrm{OH}+\mathrm{VOC}$ reaction. Taking this yield into account, the signals due to $\mathrm{RO}_{2}$ and $\mathrm{HO}_{2}$ radicals become

$S_{\mathrm{RO}_{2}}=S_{\mathrm{OH}_{0}} \cdot C_{\mathrm{OH} \rightarrow \mathrm{RO}_{2}} \cdot(1-y) \cdot C_{\mathrm{RO}_{2} \rightarrow \mathrm{OH}}$,

$S_{\mathrm{HO}_{2} \text { total }}=S_{\mathrm{OH}_{0}} \cdot C_{\mathrm{OH} \rightarrow \mathrm{RO}_{2}} \cdot y \cdot C_{\mathrm{HO}_{2} \rightarrow \mathrm{OH}}+S_{\mathrm{HO}_{2}} \cdot$
The measured $\mathrm{OH}$ signal under these conditions $\left(S_{\mathrm{RO}_{x}}\right)$ reflects the contribution of $\mathrm{RO}_{2}, \mathrm{HO}_{2}$, and unreacted $\mathrm{OH}$ radicals (experimental mode 4):

$$
\begin{aligned}
S_{\mathrm{RO}_{x}} & =S_{\mathrm{RO}_{2}}+S_{\mathrm{HO}_{2} \text { total }}+S_{\mathrm{OH}+\mathrm{VOC}}, \\
S_{\mathrm{RO}_{x}} & =\left(S_{\mathrm{OH}_{0}} \cdot C_{\mathrm{OH} \rightarrow \mathrm{RO}_{2}} \cdot(1-y) \cdot C_{\mathrm{RO}_{2} \rightarrow \mathrm{OH}}\right) \\
& +\left(S_{\mathrm{OH}_{0}} \cdot C_{\mathrm{OH} \rightarrow \mathrm{RO}_{2}} \cdot y \cdot C_{\mathrm{HO}_{2} \rightarrow \mathrm{OH}}+S_{\mathrm{HO}_{2}}\right) \\
& +S_{\mathrm{OH}+\mathrm{VOC}}
\end{aligned}
$$

Combining Eqs. (3), (6), and (9a) results in an expression for the fraction of $\mathrm{RO}_{2}$ radicals converted to $\mathrm{HO}_{2}\left(f_{\mathrm{RO}_{2} \rightarrow \mathrm{HO}_{2}}\right)$ that can be expressed as the measured signals for each experimental mode $\left(S_{\mathrm{OH}}, S_{\mathrm{HO}_{x}}, S_{\mathrm{OH}+\mathrm{VOC}}, S_{\mathrm{RO}_{x}}\right)$ as seen in Eq. (10):

$$
\begin{aligned}
& f_{\mathrm{RO}_{2} \rightarrow \mathrm{HO}_{2}} \\
& =\frac{S_{\mathrm{RO}_{x}}-S_{\mathrm{HO}_{x}}+S_{\mathrm{OH}}-S_{\mathrm{OH}+\mathrm{VOC}}-S_{\mathrm{OH}_{0}} \cdot C_{\mathrm{OH} \rightarrow \mathrm{RO}_{2}} \cdot y \cdot C_{\mathrm{HO}_{2} \rightarrow \mathrm{OH}}}{S_{\mathrm{OH}_{0}} \cdot C_{\mathrm{OH} \rightarrow \mathrm{RO}_{2}} \cdot(1-y) \cdot C_{\mathrm{HO}_{2} \rightarrow \mathrm{OH}}} .
\end{aligned}
$$

When the yield of $\mathrm{HO}_{2}$ from the $\mathrm{OH}+\mathrm{VOC}$ reaction is zero $(y=0)$, and under conditions where all the $\mathrm{OH}$ radicals are converted to $\mathrm{RO}_{2}\left(S_{\mathrm{OH}+\mathrm{VOC}}=0\right)$, the above equation (with Eqs. 3 and 4) simplifies to the following:

$$
\begin{aligned}
f_{\mathrm{RO}_{2} \rightarrow \mathrm{HO}_{2}} & =\frac{S_{\mathrm{RO}_{x}}-S_{\mathrm{HO}_{x}}+S_{\mathrm{OH}}}{S_{\mathrm{OH}_{0}} \cdot C_{\mathrm{OH} \rightarrow \mathrm{RO}_{2}} \cdot C_{\mathrm{HO}_{2} \rightarrow \mathrm{OH}}} \\
& =\frac{S_{\mathrm{RO}_{x}}-S_{\mathrm{HO}_{x}}+S_{\mathrm{OH}}}{\left(S_{\mathrm{HO}_{x}}-S_{\mathrm{OH}}\right) \cdot C_{\mathrm{OH} \rightarrow \mathrm{RO}_{2}}} .
\end{aligned}
$$

Because this method cannot distinguish between the different peroxy radicals that could be produced from each $\mathrm{OH}+\mathrm{VOC}$ reaction, the measured conversion efficiency reflects the average conversion efficiency of all peroxy radicals for a given VOC.

\section{Results}

The pressure and flow conditions for the three campaigns conducted with the IU LIF-FAGE instrument are summarized in Table 1. For each characterization, the flow rate of 
Table 1. Configuration of the IU-FAGE instrument during various previous field campaigns.

\begin{tabular}{|c|c|c|c|}
\hline & CalNex & CABINEX & MCMA-2006 \\
\hline Cell pressure $(\mathrm{hPa})$ & 5.5 & 10.0 & 7.2 \\
\hline Orifice diameter (mm) & 0.64 & 1.02 & 1.02 \\
\hline Sample flow rate (SLPM) & 3.4 & 8.5 & 10 \\
\hline $\mathrm{NO}$ (molecules $\mathrm{cm}^{-3}$ ) (for $1 \mathrm{sccm}$ flow) & $2.9 \times 10^{13}$ & $2.1 \times 10^{13}$ & $1.3 \times 10^{13}$ \\
\hline
\end{tabular}

$\mathrm{NO}$ addition was kept constant at $1 \mathrm{sccm}$ in order to determine the impact of the different operating conditions on the measured $\mathrm{RO}_{2}$-to- $\mathrm{HO}_{2}$ conversion efficiencies. This is the NO flow rate used during the MCMA 2006, CABINEX and CalNex campaigns and resulted in $\mathrm{HO}_{2}$-to-OH conversion efficiencies that were similar to those measured during both the CABINEX and the CalNex campaigns. However, the measured $\mathrm{HO}_{2}$-to-OH conversion efficiency for the MCMA 2006 campaign configuration in these experiments was approximately $20 \%$ lower than that previously reported (Dusanter et al., 2008, 2009a). The reason for this discrepancy is unclear and may indicate problems in precisely recreating the flow conditions during this campaign in these laboratory experiments. In addition, the NO flow rate was varied during MCMA-2006 in order to maximize the $\mathrm{HO}_{2}$-to- $\mathrm{OH}$ conversion efficiency and to quantify the photolytic interference associated with high NO concentrations in the detection cell. Thus, it is possible that the actual flow rate used to maximize the conversion efficiency was slightly greater than the $1 \mathrm{sccm}$ reported. Since it is not known whether the flow was greater than the $1 \mathrm{sccm}$ that was measured, or whether the flow conditions led to more efficient mixing, we chose to conduct the experiments using the measured $1 \mathrm{sccm}$ flow rate. It is difficult to quantify how the higher $\mathrm{HO}_{2}$-to-OH conversion efficiency measured during MCMA-2006 would translate into the various $\mathrm{RO}_{2}$-to- $\mathrm{HO}_{2}$ conversion efficiencies, although it is likely that many of them would be larger. As a result, the conversion efficiencies measured in this study for the MCMA-2006 configuration may represent a lower limit to the actual conversion efficiencies during the campaign.

The $\mathrm{RO}_{2}$ conversion efficiency into $\mathrm{HO}_{2}\left(f_{\mathrm{RO}_{2} \rightarrow \mathrm{HO}_{2}}\right)$ measured for the inlet conditions for the MCMA 2006, CABINEX, and CalNex campaigns are summarized in Table 2 and represent the results of several experiments similar to those illustrated in Fig. 3, with the uncertainty representing 1 standard error of the mean of the measurements. The largest $\mathrm{RO}_{2}$ interference was observed for the CalNex inlet conditions where alkenes produced interferences ranging from $83 \pm 7 \%$ for isoprene-based peroxy radicals to $96 \pm 6 \%$ for tetramethylethylene (TME)-based peroxy radicals while the conversion efficiency of aromatic, aldehydes, and ketone compounds ranged from $54 \pm 4 \%$ for methacrolein (MACR) to $91 \pm 4 \%$ for methyl vinyl ketone (MVK). The $\mathrm{RO}_{2}$-to- $\mathrm{HO}_{2}$ conversion efficiency of a number of alkanes ranged from an average measured value of $15 \pm 3 \%$ for propane-based peroxy radicals to $62 \pm 4 \%$ for octane-based peroxy radicals, with the $\mathrm{RO}_{2}$-to- $\mathrm{HO}_{2}$ conversion efficiency increasing with the carbon number. The inlet configuration and conditions used during the MCMA 2006 campaign generally resulted in lower $\mathrm{RO}_{2}$ interferences likely due to the higher flow rate (and shorter reaction time) in the detection cell and the lower NO concentration (Table 1), although the measured conversion efficiency was found to be somewhat greater for some VOCs. Under these inlet conditions the $\mathrm{RO}_{2}$-to- $\mathrm{HO}_{2}$ conversion efficiency for propane-based peroxy radicals was measured to be $22 \pm 11 \%$ while the conversion efficiency for octane-based peroxy radicals was $30 \pm 5 \%$. Because the CABINEX campaign occurred in a remote forested environment, measurements of the $\mathrm{RO}_{2}$-to- $\mathrm{HO}_{2}$ conversion efficiency focused on characterizing interferences from peroxy radicals produced from isoprene and its oxidation products (MVK and MACR), as isoprene peroxy radicals were predicted to contribute to more than $80 \%$ of the total $\mathrm{RO}_{2}$ concentration during the campaign (Griffith et al., 2013). The inlet and instrumental configuration during CABINEX resulted in a higher pressure and slower sampling rate compared to the MCMA-2006 configuration. For this instrumental configuration, the $\mathrm{RO}_{2}$-to- $\mathrm{HO}_{2}$ conversion efficiency was found to be $91 \pm 5 \%$ for isoprene-based peroxy radicals, while the conversion efficiencies for MVK and MACR were found to be $62 \pm 5$ and $30 \pm 7 \%$, respectively.

These observations are consistent with results reported for other FAGE instruments (Fuchs et al., 2011; Whalley et al., 2011) and assume that the photolysis of each VOC does not contribute to the production of radicals in these experiment. However, tests to determine whether photolysis of the various VOCs resulted in the formation of $\mathrm{HO}_{x}$ radicals in the absence of water vapor revealed that the photolysis of methyl vinyl ketone (MVK), methacrolein (MACR), methyl ethyl ketone (MEK), and toluene can lead to the production of $\mathrm{HO}_{x}$ radicals. The radical signals from the photolysis of methacrolein and toluene were small and negligible relative to the total $\mathrm{HO}_{x}$ signal produced from the photolysis of water. However, the signal from the photolysis of MVK and MEK during these tests was significant and could interfere with the measurements of the $\mathrm{RO}_{2}$-to- $\mathrm{HO}_{2}$ conversion efficiency. These results are in contrast to that reported by Fuchs et al. (2011), who found that the photolysis of VOCs during similar tests in dry air did not produce any radicals. The reason for this discrepancy is unclear but may be related to 
Table 2. Average measured $f_{\mathrm{RO}_{2}} \rightarrow \mathrm{HO}_{2}$ for various alkenes and alkanes under different inlet conditions. Uncertainties represents the standard error of the mean from all individual experiments, with the number of experiments shown in parentheses.

\begin{tabular}{lrrrrr}
\hline Compounds & $\begin{array}{r}\text { 4 Torr @ } \\
\text { 3.4 SLPM } \\
\text { (CalNex) }\end{array}$ & $\begin{array}{r}\text { 7.5 Torr @ } \\
\text { 8.5 SLPM } \\
\text { (CABINEX) }\end{array}$ & $\begin{array}{r}\text { 5 Torr @ } \\
\text { 10 SLPM } \\
\text { (MCMA-2006) }\end{array}$ & $\begin{array}{r}\text { Fuchs } \\
\text { et al. }^{\text {a }}\end{array}$ & $\begin{array}{r}\text { Whalley } \\
\text { et al. }^{\text {b }}\end{array}$ \\
\hline$C\left(\mathrm{HO}_{2} \rightarrow \mathrm{OH}\right)$ & $0.67 \pm 0.01(67)$ & $0.90 \pm 0.02(47)$ & $0.80 \pm 0.01(81)$ & - & - \\
Isoprene & $0.83 \pm 0.07(5)$ & $0.91 \pm 0.05(9)$ & $0.84 \pm 0.05(6)$ & $0.79 \pm 0.05$ & $0.92 \pm 0.04$ \\
MVK & $0.91 \pm 0.04(10)$ & $0.62 \pm 0.05(21)$ & $0.72 \pm 0.04(15)$ & $0.60 \pm 0.06$ & - \\
MACR & $0.54 \pm 0.04(4)$ & $0.30 \pm 0.07(5)$ & $0.32 \pm 0.07(11)$ & $0.58 \pm 0.17$ & - \\
MEK & $0.57 \pm 0.06(6)$ & $0.62 \pm 0.01(2)$ & $0.51 \pm 0.07(9)$ & - & - \\
Ethene & $0.65 \pm 0.05(18)$ & $0.81 \pm 0.06(7)$ & $0.86 \pm 0.06(9)$ & $0.85 \pm 0.05$ & $1.00 \pm 0.08$ \\
trans-2-Butene & $0.92 \pm 0.04(4)$ & - & $0.72 \pm 0.03(6)$ & - & - \\
TME & $0.96 \pm 0.06(2)$ & - & $0.64 \pm 0.06(8)$ & - & - \\
Toluene & $0.65 \pm 0.07(4)$ & - & $0.32 \pm 0.10(6)$ & - & - \\
Propane & $0.15 \pm 0.03(4)$ & - & $0.22 \pm 0.11(2)$ & - & $0.03 \pm 0.01$ \\
$n$-Butane & $0.31 \pm 0.03(4)$ & $0.30 \pm 0.03(3)$ & $0.23 \pm 0.05(4)$ & - & $0.18 \pm 0.01$ \\
$n$-Octane & $0.62 \pm 0.04(5)$ & - & $0.30 \pm 0.05(5)$ & - & - \\
\hline
\end{tabular}

${ }^{\mathrm{a}}$ Fraction of conversion for $\mathrm{RO}_{2}$-to- $\mathrm{HO}_{2}$ conversion for the Jülich LIF instrument (Fuchs et al., 2011). ${ }^{\mathrm{b}}$ Conversion efficiencies of $\mathrm{RO}_{2}$ to $\mathrm{OH}$ for the Leeds LIF instrument referenced to ethene (Whalley et al., 2013).

differences in the UV flux produced by the different mercury lamps or impurities associated with the VOC samples (Tables S1 and S2). Addition of water vapor may reduce the $\mathrm{HO}_{x}$ radical production from photolysis of these VOCs due to quenching of the excited VOC, and as a result it is difficult to quantify the interference in these experiments. However, any interference from $\mathrm{HO}_{x}$ radicals produced from the photolysis of MVK and MEK would result in higher apparent conversion efficiencies, as they could represent an additional source of $\mathrm{HO}_{x}$ radicals when the VOCs are added, and could contribute to the higher $\mathrm{RO}_{2}$-to- $\mathrm{HO}_{2}$ conversion efficiency reported here for MVK compared to that reported by Fuchs et al. (2011).

As previously observed, the $\mathrm{RO}_{2}$-to- $\mathrm{HO}_{2}$ conversion efficiency of alkene-based $\beta$-hydroxyalkyl peroxy radicals was found to be greater than the conversion efficiency of alkanebased alkyl peroxy radicals (Fuchs et al., 2011). As discussed above, this is due to due to the ability of the $\beta$-hydroxyalkoxy radicals produced from the $\mathrm{RO}_{2}+\mathrm{NO}$ reaction to rapidly decompose to form a hydroxyalkyl radical. The hydroxyalkyl radical reacts rapidly with $\mathrm{O}_{2}$ in the FAGE detection cell, leading to the production of a carbonyl compound and $\mathrm{HO}_{2}$. However, the ability of large alkoxy radicals to rapidly isomerize and decompose (Atkinson, 1997; Finlayson-Pitts and Pitts Jr., 2000) also results in a rapid production of $\mathrm{HO}_{2}$ radicals and a larger conversion efficiency.

In general, reducing the reaction time in the IU-FAGE instrument reduces the conversion of these peroxy radicals to $\mathrm{HO}_{2}$, as illustrated by the reduced conversion efficiencies between the CalNex and MCMA operating conditions for the majority of the VOCs tested. However, the measured conversion efficiencies of some of the tested VOCs did not always display this behavior, and the reasons for the discrep- ancies are unclear. For example, the conversion efficiency for ethene peroxy radicals was lower for the CalNex configuration compared to the CABINEX and MCMA configurations even though the overall flow rate was slower for the CalNex configuration. However, the $\mathrm{HO}_{2}$-to-OH conversion efficiency was also lower for this inlet configuration, suggesting that reaction time may not be the only factor limiting the conversion efficiency under these instrument conditions. Similarly, the conversion efficiency of MVK and MACR measured for the CABINEX instrument configuration was lower than that measured for the MCMA inlet configuration, even though the overall slower flow rate in the CABINEX configuration leads to a longer reaction time in the IU-FAGE detection cell. This may suggest that the chemistry of peroxy radicals produced from the $\mathrm{OH}$-initiated oxidation of MVK and MACR is different than that of the peroxy radicals produced from the $\mathrm{OH}$-initiated oxidation of alkenes and alkanes, with competing channels that result in a more complex dependence on reaction time. As discussed in Fuchs et al. (2011), the fates of the peroxy radicals produced by the $\mathrm{OH}$-initiated oxidation of MVK and MACR are not well known. For the peroxy radicals produced from the $\mathrm{OH}$-initiated oxidation of MVK, three decomposition channels are possible, with two channels potentially leading to fast $\mathrm{HO}_{2}$ production and one likely leading to slower $\mathrm{HO}_{2}$ production (Fuchs et al., 2011). For the peroxy radicals produced from the $\mathrm{OH}$-initiated oxidation of MACR, the channel that leads to the formation of a hydroxyalkyl peroxy radical likely leads to fast $\mathrm{HO}_{2}$ production, while the channel that leads to the formation of an acyl peroxy radical would lead to much slower $\mathrm{HO}_{2}$ production (Fuchs et al., 2011). 


\section{Discussion}

\section{1 $\mathrm{RO}_{2}$ radical concentrations during MCMA-2006}

The previous analysis of the $\mathrm{HO}_{2}$ radical concentrations during the Mexico City Metropolitan Area 2006 campaign did not take into account interferences from $\mathrm{RO}_{2}$ radicals (Dusanter et al., 2009b). As discussed above, the instrumental conditions during MCMA-2006 resulted in the conversion of a fraction of $\mathrm{RO}_{2}$ radicals to $\mathrm{HO}_{2}$, resulting in the measurements reflecting $\mathrm{HO}_{2} *=\mathrm{HO}_{2}+\alpha \mathrm{RO}_{2}$ and overestimating the actual $\mathrm{HO}_{2}$ concentrations. To determine the fraction $(\alpha)$ of $\mathrm{RO}_{2}$ radicals likely detected during the $\mathrm{HO}_{2}$ measurements, the $\mathrm{RO}_{2}$ radical concentrations during MCMA2006 that were previously modeled using the Regional Atmospheric Chemistry Mechanism (RACM) were used to calculate the modeled $\mathrm{HO}_{2} *$ concentrations (Dusanter et al., 2009b).

As discussed in Dusanter et al. (2009b), the RACM model is a condensed chemical mechanism that describes the gasphase oxidation of 17 inorganic and 32 organic species. Kinetic parameters for the reactions of $\mathrm{OH}, \mathrm{O}_{3}$, and $\mathrm{NO}_{3}$ with inorganic species and for reactions involving organic species treated explicitly in RACM (methane, ethane, ethene, formaldehyde, glyoxal, methyl peroxide, and isoprene) were updated using the NASA Jet Propulsion Laboratory database (Sanders et al., 2006). Rate constants and branching ratios for $\mathrm{OH}, \mathrm{O}_{3}$, and $\mathrm{NO}_{3}$ reactions with surrogate species were used as described in the RACM model (Stockwell et al., 1997). Heterogeneous chemistry, such as the incorporation of trace gases into aerosols, was not included.

The peroxy radical fractions calculated by the model are illustrated in Fig. 4 for 09:00, 12:00, 18:00 (local times), and the overall diurnal average. Alkane-based peroxy radicals (red shades) include methyl peroxy (RACM category $\mathrm{CH} 3 \mathrm{O} 2$ ), ethyl peroxy (ETHP), peroxy radicals formed from the oxidation of alkanes, esters, and alkynes exhibiting $\mathrm{OH}$ rate constants lower than $3.4 \times 10^{-12} \mathrm{~cm}^{3}$ molecule ${ }^{-1} \mathrm{~s}^{-1}$ (HC3P); peroxy radicals formed from alkanes, esters, and alkynes characterized by $\mathrm{OH}$ rate constants ranging from $3.4 \times 10^{-12}$ to $6.8 \times 10^{-12} \mathrm{~cm}^{3}$ molecule ${ }^{-1} \mathrm{~s}^{-1}$ (HC5P); and peroxy radicals formed from alkanes, esters, and alkynes whose $\mathrm{OH}$ rate constants are larger than $6.8 \times 10^{-12} \mathrm{~cm}^{3}$ molecule ${ }^{-1} \mathrm{~s}^{-1}$ (HC8P). Alkene-based peroxy radicals (blue shades) include peroxy radicals from the oxidation of ethene (ETEP), external olefins (OLTP), internal olefins (OLIP), isoprene (ISOP), and from $\alpha$-pinene and other cyclic terpenes with one double bond (APIP). Aromatic peroxy radicals (green shades) include species produced during the oxidation of toluene (TOLP), xylenes (XYLP), and cresol (CSLP). The carbonyl-based peroxy radicals (grey shades) include saturated (ACO3) and unsaturated (TCO3) acyl peroxyl radicals.

The total average modeled $\mathrm{RO}_{2}$ concentration from 09:00 to $18: 00$ consisted of $54 \%$ alkane-based, $27 \%$ alkene-based, and $14 \%$ aromatic-based peroxy radicals (Fig. 4). On average, the modeled composition of peroxy radicals was relatively constant throughout the day during the MCMA campaign. The modeled relative contribution of aromatic-based peroxy radicals was greater in the morning, which is consistent with the observed elevated concentrations of benzene and toluene during the morning hours (Dusanter et al., 2009b).

\subsection{Implications of $\mathrm{RO}_{2}$ interferences for $\mathrm{HO}_{2}$ measurements during MCMA-2006}

The modeled diurnal average concentrations of total $\mathrm{RO}_{2}$ radicals during MCMA is shown in Fig. 5, along with the modeled $\mathrm{HO}_{2}$ concentrations and the measured $\mathrm{HO}_{2} *$ concentrations. As discussed in Dusanter et al. (2009b), the modeled $\mathrm{HO}_{2}$ concentrations were in good agreement with the measurements during the afternoon but the model underestimated the measured $\mathrm{HO}_{2}$ concentrations during the morning hours by a factor of approximately 2 to 5 . However, these conclusions were based on the assumption that the measured $\mathrm{HO}_{2}$ concentrations were free from interferences and could be compared to the modeled $\mathrm{HO}_{2}$ concentrations. Based on the conversion efficiencies reported for $\mathrm{RO}_{2}$ radicals in the present study, it is clear that the MCMA measurements represent an upper limit to the actual $\mathrm{HO}_{2}$ concentrations and should be compared to the modeled $\mathrm{HO}_{2} *=\mathrm{HO}_{2}+\alpha \mathrm{RO}_{2}$ concentrations.

The RACM modeled $\mathrm{HO}_{2}$ * concentrations were calculated by applying the measured $\mathrm{RO}_{2}$-to- $\mathrm{HO}_{2}$ conversion efficiencies for the instrumental conditions reported in Table 2 for MCMA-2006 using Eq. (12):

$$
\begin{aligned}
\mathrm{HO}_{2}^{*} & =\mathrm{HO}_{2}+0.84 \cdot \mathrm{ISOP}+0.68 \cdot \mathrm{OLIP}+0.68 \cdot \mathrm{OLTP} \\
& +0.86 \cdot \mathrm{ETEP}+0.32 \cdot \mathrm{TOLP}+0.32 \cdot \mathrm{XYLP} \\
& +0.32 \cdot \mathrm{CSLP}+0.72 \cdot \mathrm{APIP}+0.22 \cdot \mathrm{HC} 3 \mathrm{P} \\
& +0.22 \cdot \mathrm{HC} 5 \mathrm{P}+0.30 \cdot \mathrm{HC} 8 \mathrm{P}+0.05 \cdot \mathrm{CH} 3 \mathrm{O} 2 \\
& +0.07 \cdot \mathrm{ETHP}+0.32 \cdot \mathrm{ACO} 3+0.32 \cdot \mathrm{TCO} 3 \\
& +0.72 \cdot \mathrm{KETP} .
\end{aligned}
$$

The contribution for isoprene peroxy radicals (ISOP), ethene peroxy radicals (ETEP), and toluene peroxy radicals (TOLP) were taken directly from Table 2 . The average $\mathrm{RO}_{2}$-to- $\mathrm{HO}_{2}$ conversion efficiency for trans-2-butene and tetramethylethylene-based peroxy radicals was used for the conversion efficiency of peroxy radicals from internal olefins (OLIP) and external olefins (OLTP), while the conversion efficiency for trans-2-butene was used for the conversion efficiency for $\alpha$-pinene and other cyclic terpene peroxy radicals (APIP). The measured conversion efficiency for toluene-based peroxy radicals was used to represent the conversion efficiency for xylene (XYLP) and cresol (CSLP) peroxy radicals. The conversion efficiency of methacroleinbased peroxy radicals was used to represent the conversion 

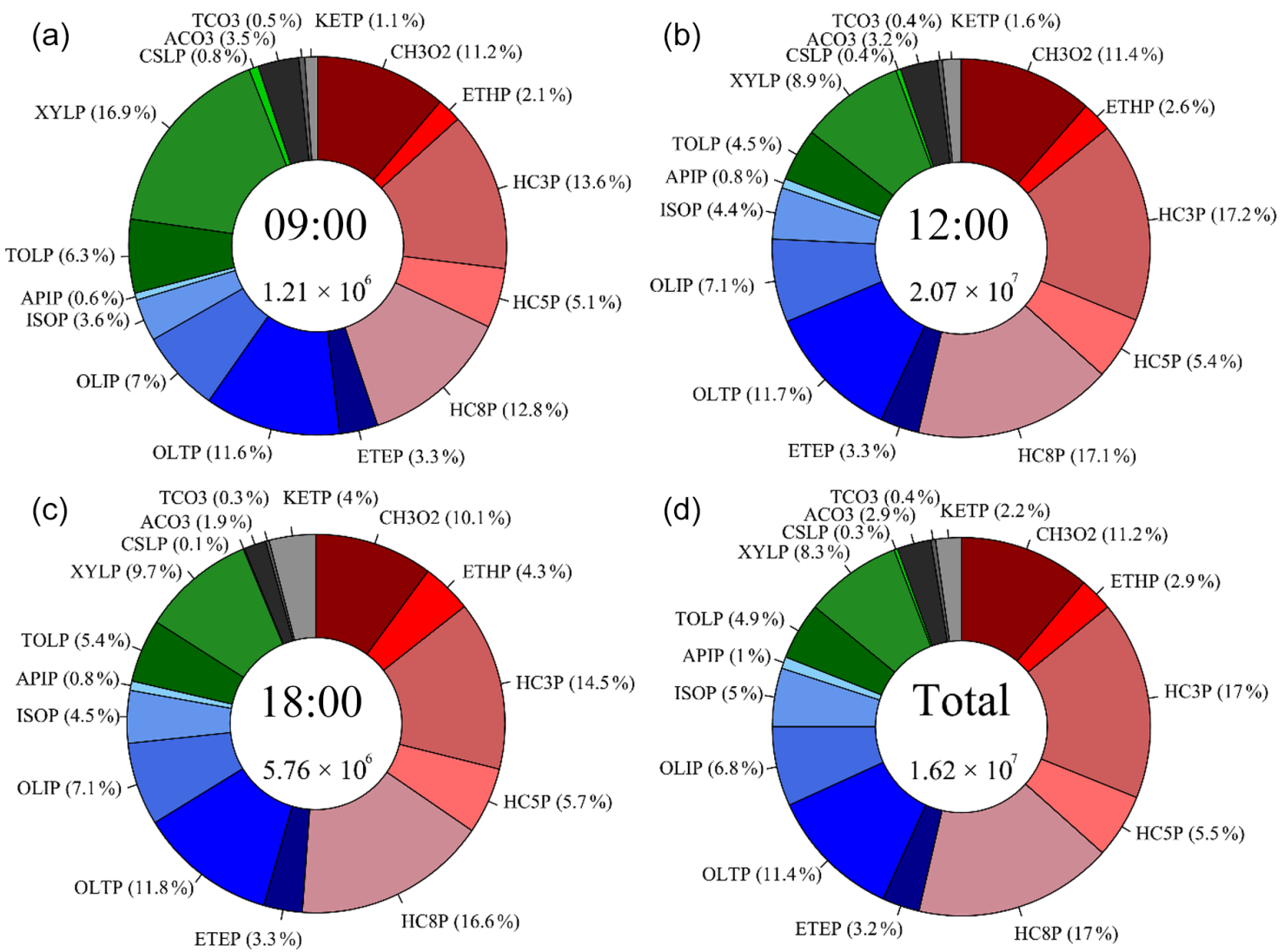

Figure 4. Modeled average peroxy radical contributions for the MCMA 2006 field campaign at 09:00 (a), 12:00 (b), 18:00 (c), and for the average campaign (d). Shades of red represent alkanes, shades of blue represent alkenes, shades of green represent aromatics, and shades of grey represent acyl peroxy radicals. Individual RACM peroxy radical categories are defined in Sect. 4.2.

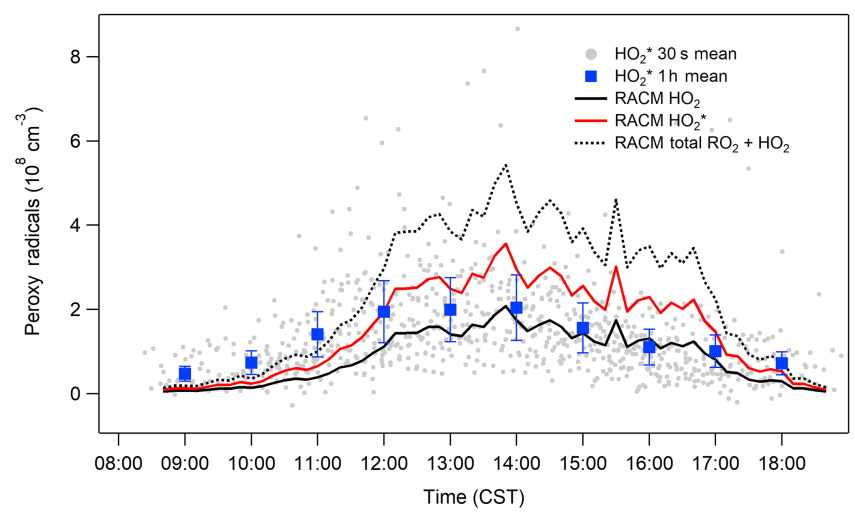

Figure 5. Diurnal average $\mathrm{HO}_{2} *$ measurements from MCMA-2006. The grey solid circles are $30 \mathrm{~s}$ averages and solid blue square symbols are binned $1 \mathrm{~h}$ averages. The solid black line represents the RACM modeled $\mathrm{HO}_{2}$, the solid red line represents the modeled $\mathrm{HO}_{2}$ *, and the dotted black line represents the total modeled $\mathrm{RO}_{2}+\mathrm{HO}_{2}$. The error bars reflect the calibration accuracy of the measurements $( \pm 36 \%, 2 \sigma)$. efficiency of acetyl peroxy and higher saturated acyl peroxy radicals (ACO3) as well as unsaturated acyl peroxy radicals (TCO3), while the conversion efficiency of methyl vinyl ketone-based peroxy radicals was used to represent the efficiency of ketone-based peroxy radicals (KETP).

The overall average contribution of peroxy radicals to the modeled $\mathrm{HO}_{2} *$ and the relative contribution of each RACM peroxy radical category to the $\mathrm{RO}_{2}$ interference are shown in Fig. 6. Because the $\mathrm{HO}_{2}$-to-OH conversion efficiency of $80 \%$ in these experiments was approximately $20 \%$ lower than the conversion efficiency measured during the campaign (Dusanter et al., 2008, 2009a), the relative peroxy radical contributions illustrated in this figure are likely lower limits to the actual contribution during the campaign.

On average, $\mathrm{RO}_{2}$ radicals contributed to approximately $35 \%$ of the total modeled $\mathrm{HO}_{2}^{*}$ (Fig. 6). While alkanes compose the majority of the modeled peroxy radicals (Fig. 4), they only contributed to about $29 \%$ of the $\mathrm{RO}_{2}$ interference, whereas alkenes contributed to approximately $51 \%$ of the interference (Fig. 6). While isoprene peroxy radicals contributed to only $5 \%$ of the total $\mathrm{RO}_{2}$ concentration, they contributed approximately $11 \%$ to the interference. 
(a)

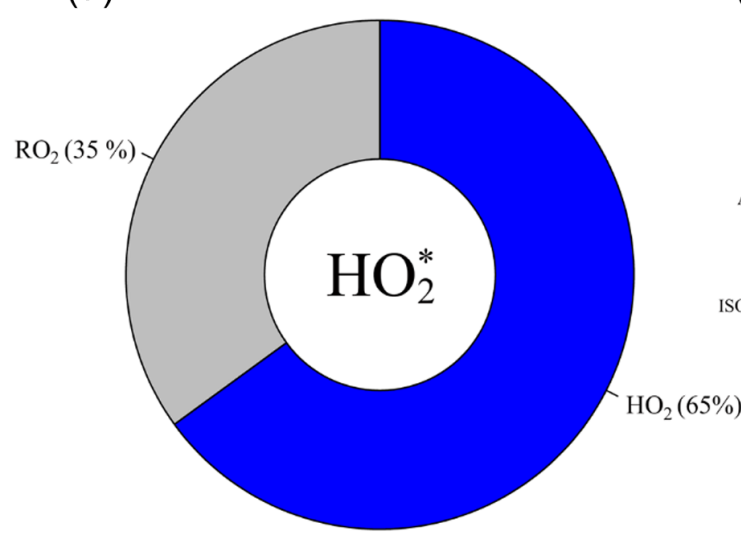

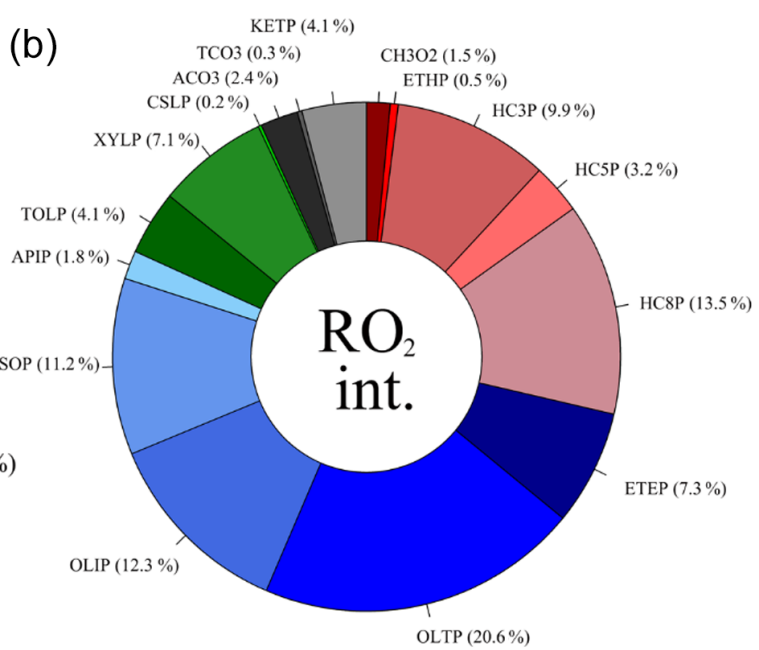

Figure 6. Modeled speciation of the $\mathrm{RO}_{2}$ interference for MCMA-2006. The pie chart on the left is the modeled $\mathrm{HO}_{2} *$ composition after adding the fraction of $\mathrm{RO}_{2}$ interference to the modeled $\mathrm{HO}_{2}$. The pie chart on the right is the composition of the $\mathrm{RO}_{2}$ interference.

The overall contribution of $\mathrm{RO}_{2}$ radicals to the measured $\mathrm{HO}_{2} *$ concentrations in this environment is similar to that observed during the CalNex campaign, where $\mathrm{RO}_{2}$ radicals were modeled to contribute to approximately $30 \%$ of the measured $\mathrm{HO}_{2} *$ concentrations, although during CalNex peroxy radicals from isoprene (ISOP) and its oxidation products accounted for approximately $40-50 \%$ of the modeled interference and olefins (OLTP, OLIP) contributed approximately 20-30\% (Griffith et al., 2016). Unlike these urban environments, in forested environments where the $\mathrm{OH}$ reactivity is dominated by isoprene and other unsaturated biogenic emissions, isoprene and other biogenic hydroxyl alkyl peroxy radicals can be the dominant peroxy radicals and can make a significant contribution to the measured $\mathrm{HO}_{2} *$ concentrations due to their high conversion efficiency to $\mathrm{HO}_{2}$ in the FAGE detection cell (Table 2). For example, during the CABINEX campaign in a northern Michigan forest, isoprene peroxy radicals were modeled to be the dominant peroxy radical in this environment and the main contributor to the interference, contributing to approximately $50 \%$ of the modeled $\mathrm{HO}_{2} *$ concentrations during the daytime (Griffith et al., 2013). As a result, previous measurements of $\mathrm{HO}_{2}$ in these environments by LIF-FAGE or other chemical conversion techniques are likely influenced by an interference from $\beta$-hydroxyalkyl peroxy radicals such as those produced by the $\mathrm{OH}$-initiated oxidation of isoprene and other biogenic emissions. While it is possible to subtract the modeled speciated $\mathrm{RO}_{2}$ concentrations from the measured $\mathrm{HO}_{2}{ }^{*}$ and compare the results to the modeled $\mathrm{HO}_{2}$, this method increases the uncertainty associated with the measured concentrations due to the additional uncertainty associated with the modeled $\mathrm{RO}_{2}$ concentrations as well as the uncertainties associated with the measured $\mathrm{RO}_{2}$-to- $\mathrm{HO}_{2}$ conversion efficiencies. We estimate the uncertainty associated with the RACM mod- eled $\mathrm{RO}_{2}$ to be approximately $\pm 70 \%(2 \sigma)$, which is similar to that for the modeled $\mathrm{HO}_{2}$ (Dusanter et al., 2009b). As a result, we prefer to compare the modeled $\mathrm{HO}_{2} *$ to the measured $\mathrm{HO}_{2} *$.

The diurnal average modeled $\mathrm{HO}_{2} *$ concentrations for the MCMA 2006 campaign are also shown in Fig. 5. As can be seen in this figure, the model overestimates the measured $\mathrm{HO}_{2} *$ by approximately $35 \%$ between 12:00 and 17:00 CST, although the modeled results are generally close to the upper bound of the calibration accuracy $(36 \%, 2 \sigma)$ (Dusanter et al., 2009b). As discussed above, the modeled $\mathrm{HO}_{2}{ }^{*}$ is likely a lower limit given that the $\mathrm{RO}_{2}$-to- $\mathrm{HO}_{2}$ conversion efficiencies during the campaign may be greater than shown in Table 2 due to the higher $\mathrm{HO}_{2}$-to-OH conversion efficiency measured during the campaign. Although the measured $\mathrm{HO}_{2} *$ is still likely to be within the overall uncertainty of the model, which was estimated to be approximately a factor of 1.7 (Dusanter et al., 2009b), these results suggest that the model likely overestimates the measured concentrations during the afternoon.

These results are in contrast to the results from the CalNex campaign, where the simulations using the RACM2 model tended to underestimate the measured $\mathrm{HO}_{2} *$ concentrations during the week, when NO mixing ratios were greater than $4 \mathrm{ppb}$ (Griffith et al., 2016). The reason for this difference between the campaigns is unclear but may be related to the relative concentrations of dicarbonyl species and their treatment in the RACM and RACM2 models. Dusanter et al. (2009b) demonstrated that the RACM model results for MCMA-2006 were highly sensitive to the concentrations of dicarbonyl species in the model, with the model significantly overpredicting the concentration of $\mathrm{HO}_{x}$ radicals when unmeasured concentrations of these species were not constrained. Daytime average measured glyoxal mixing ratios during MCMA- 


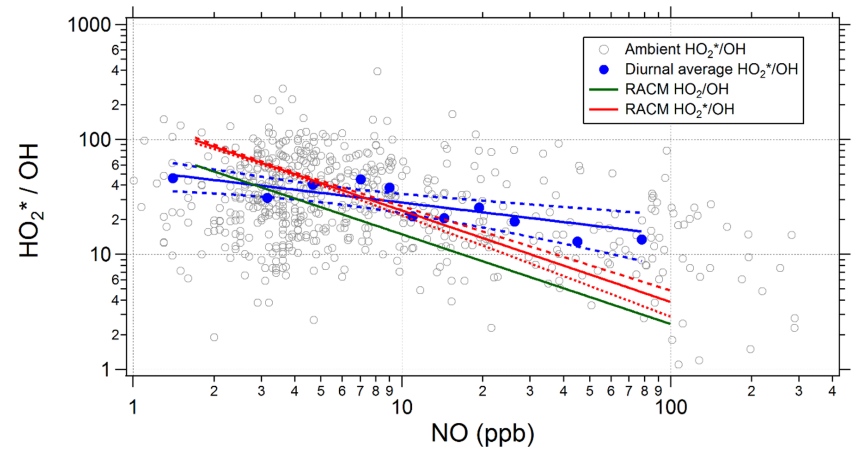

Figure 7. Correlation plot for $\mathrm{HO}_{2} * / \mathrm{OH}$ vs. NO. Small grey circles are individual measurements recorded for the whole campaign. Large blue circles are average values calculated on binned NO data and the blue line is a fit to the average measurements. The modelcalculated $\mathrm{HO}_{2} / \mathrm{OH}$ ratio is displayed by the green line for the campaign averaged measurements, while the red line represents the modeled $\mathrm{HO}_{2} * / \mathrm{OH}$ ratio. Dashed lines are the $95 \%$ confidence interval from the nonlinear power regressions.

2006 were approximately $0.4 \mathrm{ppb}$ (Dusanter et al., 2009b), which were greater than the maximum daytime mixing ratios of $0.16 \mathrm{ppb}$ during CalNex (Washenfelder et al., 2011), suggesting that the MCMA-2006 results may be more sensitive to the treatment of dicarbonyl chemistry compared to CalNex. Additional analysis and modeling will be needed to resolve this issue.

While the model tends to overestimate the measured $\mathrm{HO}_{2}$ * concentrations during the afternoon, it underestimates the measured $\mathrm{HO}_{2} *$ concentrations in the morning by a factor of 3 between 09:00 and 11:00. As discussed in Dusanter et al. (2009b), this may suggest that a significant radical source may be missing from current atmospheric models under polluted conditions. Similar results were observed in Wangdu, China, by Tan et al. (2017). In this study, total peroxy radical concentrations were measured by chemical conversion to $\mathrm{HO}_{2}$ in an external reactor with subsequent detection of $\mathrm{HO}_{2}$ (after chemical conversion to $\mathrm{OH}$ ) in an LIF-FAGE instrument. They also measured $\mathrm{HO}_{2}$ radicals using a second LIFFAGE detection axis that minimized interferences from $\mathrm{RO}_{2}$ radicals. They found that a model using the updated RACM2 mechanism was able to reproduce the observed $\mathrm{HO}_{2}$ concentrations during the day but underestimated the observed total $\mathrm{RO}_{2}$ concentration by a factor of 3 to 5 in the morning when NO concentrations were higher than 1 ppbv. The observed $\mathrm{RO}_{2}$ concentrations could be explained by a missing $\mathrm{RO}_{2}$ source of $2 \mathrm{ppbv} \mathrm{h}^{-1}$ (Tan et al., 2017).

Dusanter et al. (2009b) also compared the measured $\mathrm{HO}_{2} * / \mathrm{OH}$ ratio to the RACM modeled $\mathrm{HO}_{2} / \mathrm{OH}$ ratio and found that the model underpredicted the observed ratio, especially under conditions where the mixing ratio of NO was greater than $5 \mathrm{ppb}$. At NO mixing ratios of $10 \mathrm{ppb}$, the model underestimated the measured ratio by a factor of 2 (Dusanter et al., 2009b). However, comparing the measured
$\mathrm{HO}_{2} * / \mathrm{OH}$ ratio to the modeled $\mathrm{HO}_{2} * / \mathrm{OH}$ ratio improves the agreement even though the model tends to overpredict both $\mathrm{OH}$ and $\mathrm{HO}_{2} *$ in the afternoon (Fig. 7). This may indicate that there is either a missing sink of $\mathrm{HO}_{x}$ radicals in the model or a miscalculation of the relative rates of initiation and/or termination. At an NO mixing ratio of $10 \mathrm{ppb}$ the modeled $\mathrm{HO}_{2} * / \mathrm{OH}$ ratio is in good agreement with the measurements, although it still underestimates the measured $\mathrm{HO}_{2} * / \mathrm{OH}$ ratio at higher $\mathrm{NO}$ mixing ratios by as much as a factor of 4 , and may also overestimate the $\mathrm{HO}_{2} * / \mathrm{OH}$ ratio for mixing ratios of $\mathrm{NO}$ less than $5 \mathrm{ppb}$ by as much as a factor of 2 (Fig. 7). It is interesting to note that a model underestimation of the total $\mathrm{OH}$ reactivity at high $\mathrm{NO}$ mixing ratios may contribute to this discrepancy. Unfortunately, total $\mathrm{OH}$ reactivity was not measured during MCMA-2006 and the reliability of the model to simulate it could not be assessed. Similar results were observed for the CalNex campaign (Griffith et al., 2016), which included direct measurements of the total $\mathrm{OH}$ reactivity. Although accounting for the missing reactivity in the analysis of the CalNex data improved the agreement between the measured and modeled $\mathrm{HO}_{2} * / \mathrm{OH}$ ratio, the model still underestimates the measured ratio at high mixing ratios of NO (Griffith et al., 2016). These results suggest that our understanding of the radical propagation chemistry under high NO conditions may be incomplete.

\section{Summary and conclusions}

The $\mathrm{RO}_{2}$ interference associated with measurements of $\mathrm{HO}_{2}$ by the IU-FAGE instrument was characterized for three different instrument configurations that were used in previous field campaigns (MCMA 2006, CABINEX 2009, and CalNex 2010). Similar to that reported for other LIF-FAGE instruments, the $\mathrm{RO}_{2}$-to- $\mathrm{HO}_{2}$ conversion efficiency was highest for alkene- and aromatic-based $\mathrm{RO}_{2}$ radicals, producing higher levels of interference, while the conversion efficiency of alkane-based $\mathrm{RO}_{2}$ radicals was less but increased with increasing carbon number. In general, the conversion efficiency was higher for instrument configurations that involved slower sampling flow rates and longer reaction times between the peroxy radicals and NO in the detection cell.

The similarities in the measured $\mathrm{RO}_{2}$ conversion efficiencies reported here with those reported for other LIF-FAGE instruments suggest that the main factor controlling the conversion efficiency is the rate of reaction of $\mathrm{RO}_{2}$ radicals with $\mathrm{NO}$ and that increasing the efficiency of the conversion of $\mathrm{HO}_{2}$ to $\mathrm{OH}$ will also increase the $\mathrm{RO}_{2}$-to- $\mathrm{HO}_{2}$ conversion efficiency. Although the impact of differences in the characteristics of the low-pressure expansion in LIF-FAGE instruments cannot be ruled out, these results suggest that the interferences reported here associated with measurements of $\mathrm{HO}_{2}$ are likely similar for all instruments that measure $\mathrm{HO}_{2}$ by chemical conversion through reaction with NO. Previ- 
ous measurements of $\mathrm{HO}_{2}$ radicals by instruments using this method were likely influenced by the conversion of $\mathrm{RO}_{2}$ radicals, with measurements of $\mathrm{HO}_{2}$ in forested environments likely influenced by interferences from peroxy radicals derived from biogenic alkenes such as isoprene due to the high $\mathrm{RO}_{2}$-to- $\mathrm{HO}_{2}$ conversion efficiencies of these radicals. Because of the lower conversion efficiencies of alkane-based peroxy radicals, the impact on previous measurements in urban areas will depend on the relative concentrations of alkanes versus alkenes and aromatics contributing to the overall pool of peroxy radicals in these environments.

While this interference was taken into account to investigate the radical chemistry during CABINEX (Griffith et al., 2013) and CalNex (Griffith et al., 2016), this issue was not known when the radical measurements from the MCMA 2006 field campaign were published (Dusanter et al., 2009b). An analysis of the impact of this interference on the results for the MCMA 2006 campaign suggests that the $\mathrm{RO}_{2}$ radical contribution to the measured $\mathrm{HO}_{2} *$ concentration was approximately $35 \%$ based on the RACM modeled $\mathrm{RO}_{2}$ concentrations. Taking this interference into account, the resulting modeled $\mathrm{HO}_{2} *$ concentrations were generally greater than the measured concentrations by $35 \%$ during the afternoon, although the model results were within the calibration uncertainty of the measurements $(36 \%$ at $2 \sigma)$. Given that the modeled $\mathrm{HO}_{2} *$ concentrations likely reflect a lower limit to the interference during the campaign, these results suggest that the model likely overestimates the measured concentrations during the afternoon. However, the model still underestimates the $\mathrm{HO}_{2}$ * concentration by a factor of 3 in the morning, suggesting that the model may be missing an important radical source in the morning. Although the measured $\mathrm{HO}_{2} * / \mathrm{OH}$ ratio was in better agreement with the modeled $\mathrm{HO}_{2} * / \mathrm{OH}$ ratio compared to the modeled $\mathrm{HO}_{2} / \mathrm{OH}$ ratio, the model still significantly underestimates the $\mathrm{HO}_{2} * / \mathrm{OH}$ ratio by up to a factor of 4 for $\mathrm{NO}$ mixing ratios greater than $10 \mathrm{ppb}$, suggesting that our understanding of radical propagation under these conditions is still incomplete.

Future measurements of peroxy radicals by the IU-FAGE instrument will involve measurements at lower NO concentrations to minimize the $\mathrm{RO}_{2}$-to- $-\mathrm{HO}_{2}$ conversion efficiency. Recent experiments have demonstrated that the addition of an NO concentration of approximately $9 \times 10^{11} \mathrm{~cm}^{-3}$ results in an $\mathrm{HO}_{2}$-to-OH conversion efficiency of approximately $17 \%$ and a conversion efficiency of isoprene-based peroxy radicals to $\mathrm{HO}_{2}$ of approximately $10 \%$. Even at this low $\mathrm{HO}_{2}$-to-OH conversion efficiency, the resulting $\mathrm{HO}_{2}$ signals are still significantly greater than the limit of detection of the instrument, but at this low NO concentration the subsequent conversion of isoprene peroxy radicals to $\mathrm{OH}$ is negligible, allowing for measurements of ambient $\mathrm{HO}_{2}$ concentrations without interferences from $\mathrm{RO}_{2}$ radicals.
Data availability. Data presented in this study are available from the authors upon request (pstevens@indiana.edu).

\section{The Supplement related to this article is available online at https://doi.org/10.5194/amt-11-95-2018-supplement.}

Competing interests. The authors declare that they have no conflict of interest.

Acknowledgements. This work was supported by grants from the National Science Foundation (AGS-1104880 and AGS1440834) and the National Aeronautics and Space Administration (NNX12AE55G). We would also like to thank Stephen Griffith for his helpful insights during the early stages of this project and Jennifer Liljegren for experimental assistance.

Edited by: Andreas Richter

Reviewed by: two anonymous referees

\section{References}

Atkinson, R.: Atmospheric reactions of alkoxy and $\beta$ hydroxyalkoxy radicals, Int. J. Chem. Kinet., 29, 99-111, 1997.

Cantrell, C. A., Zimmer, A., and Tyndall, G. S.: Absorption cross sections for water vapor from 183 to $193 \mathrm{~nm}$, Geophys. Res. Lett., 24, 2195-2198, 1997.

Carslaw, N., Creasey, D. J., Harrison, D., Heard, D. E., Hunter, M. C., Jacobs, P. J., Jenkin, M. E., Lee, J. D., Lewis, A. C., Pilling, M. J., Saunders, S. M., and Seakins, P. W.: $\mathrm{OH}$ and $\mathrm{HO}_{2}$ radical chemistry in a forested region of north-western Greece, Atmos. Environ., 35, 4725-4737, 2001.

Chen, S., Ren, X., Mao, J., Chen, Z., Brune, W. H., Lefer, B., Rappenglück, B., Flynn, J., Olson, J., and Crawford, J. H.: A comparison of chemical mechanisms based on TRAMP-2006 field data, Atmos. Environ., 44, 4116-4125, 2010.

Creasey, D. J., Heard, D. E., and Lee, J. D.: Absorption crosssection measurements of water vapour and oxygen at $185 \mathrm{~nm}$. Implications for the calibration of field instruments to measure $\mathrm{OH}, \mathrm{HO}_{2}$ and $\mathrm{RO}_{2}$ radicals, Geophys. Res. Lett., 27, 1651-1654, 2000.

Creasey, D. J., Heard, D. E., and Lee, J. D.: Eastern Atlantic Spring Experiment 1997 (EASE97) 1. Measurements of $\mathrm{OH}$ and $\mathrm{HO}_{2}$ concentrations at Mace Head, Ireland, J. Geophys. Res.-Atmos., 107, 4091, https://doi.org/10.1029/2001JD000892, 2002.

Czader, B. H., Li, X., and Rappenglueck, B.: CMAQ modeling and analysis of radicals, radical precursors, and chemical transformations, J. Geophys. Res., 118, 11376-311387, 2013.

Dusanter, S., Vimal, D., and Stevens, P. S.: Technical note: Measuring tropospheric $\mathrm{OH}$ and $\mathrm{HO}_{2}$ by laser-induced fluorescence at low pressure. A comparison of calibration techniques, Atmos. Chem. Phys., 8, 321-340, https://doi.org/10.5194/acp-8321-2008, 2008. 
Dusanter, S., Vimal, D., Stevens, P. S., Volkamer, R., and Molina, L. T.: Measurements of $\mathrm{OH}$ and $\mathrm{HO}_{2}$ concentrations during the MCMA-2006 field campaign - Part 1: Deployment of the Indiana University laser-induced fluorescence instrument, Atmos. Chem. Phys., 9, 1665-1685, https://doi.org/10.5194/acp-9-16652009, 2009a.

Dusanter, S., Vimal, D., Stevens, P. S., Volkamer, R., Molina, L. T., Baker, A., Meinardi, S., Blake, D., Sheehy, P., Merten, A., Zhang, R., Zheng, J., Fortner, E. C., Junkermann, W., Dubey, M., Rahn, T., Eichinger, B., Lewandowski, P., Prueger, J., and Holder, $\mathrm{H} .:$ Measurements of $\mathrm{OH}$ and $\mathrm{HO}_{2}$ concentrations during the MCMA-2006 field campaign - Part 2: Model comparison and radical budget, Atmos. Chem. Phys., 9, 6655-6675, https://doi.org/10.5194/acp-9-6655-2009, 2009b.

Emmerson, K. M., Carslaw, N., Carpenter, L. J., Heard, D. E., Lee, J. D., and Pilling, M. J.: Urban Atmospheric Chemistry During the PUMA Campaign 1: Comparison of Modelled $\mathrm{OH}$ and $\mathrm{HO}_{2}$ Concentrations with Measurements, J. Atmos. Chem., 52, 143 164, 2005.

Emmerson, K. M., Carslaw, N., Carslaw, D. C., Lee, J. D., McFiggans, G., Bloss, W. J., Gravestock, T., Heard, D. E., Hopkins, J., Ingham, T., Pilling, M. J., Smith, S. C., Jacob, M., and Monks, P. S.: Free radical modelling studies during the UK TORCH Campaign in Summer 2003, Atmos. Chem. Phys., 7, 167-181, https://doi.org/10.5194/acp-7-167-2007, 2007.

Finlayson-Pitts, B. J. and Pitts Jr., J. N.: Chemistry of the Upper and Lower Atmosphere, Academic Press, San Diego, 2000.

Fuchs, H., Brauers, T., Dorn, H.-P., Harder, H., Häseler, R., Hofzumahaus, A., Holland, F., Kanaya, Y., Kajii, Y., Kubistin, D., Lou, S., Martinez, M., Miyamoto, K., Nishida, S., Rudolf, M., Schlosser, E., Wahner, A., Yoshino, A., and Schurath, U.: Technical Note: Formal blind intercomparison of $\mathrm{HO}_{2}$ measurements in the atmosphere simulation chamber SAPHIR during the HOxComp campaign, Atmos. Chem. Phys., 10, 12233-12250, https://doi.org/10.5194/acp-10-12233-2010, 2010.

Fuchs, H., Bohn, B., Hofzumahaus, A., Holland, F., Lu, K. D., Nehr, S., Rohrer, F., and Wahner, A.: Detection of $\mathrm{HO}_{2}$ by laser-induced fluorescence: calibration and interferences from $\mathrm{RO}_{2}$ radicals, Atmos. Meas. Tech., 4, 1209-1225, https://doi.org/10.5194/amt-4-1209-2011, 2011.

George, L. A., Hard, T. M., and O'Brien, R. J.: Measurement of free radicals $\mathrm{OH}$ and $\mathrm{HO}_{2}$ in Los Angeles smog, J. Geophys. Res.-Atmos., 104, 11643-11655, 1999.

Griffith, S. M., Hansen, R. F., Dusanter, S., Stevens, P. S., Alaghmand, M., Bertman, S. B., Carroll, M. A., Erickson, M., Galloway, M., Grossberg, N., Hottle, J., Hou, J., Jobson, B. T., Kammrath, A., Keutsch, F. N., Lefer, B. L., Mielke, L. H., O'Brien, A., Shepson, P. B., Thurlow, M., Wallace, W., Zhang, N., and Zhou, X. L.: $\mathrm{OH}$ and $\mathrm{HO}_{2}$ radical chemistry during PROPHET 2008 and CABINEX 2009 - Part 1: Measurements and model comparison, Atmos. Chem. Phys., 13, 5403-5423, https://doi.org/10.5194/acp-13-5403-2013, 2013.

Griffith, S. M., Hansen, R. F., Dusanter, S., Michoud, V., Gilman, J. B., Kuster, W. C., Veres, P. R., Graus, M., de Gouw, J. A., Roberts, J., Young, C., Washenfelder, R., Brown, S. S., Thalman, R., Waxman, E., Volkamer, R., Tsai, C., Stutz, J., Flynn, J. H., Grossberg, N., Lefer, B., Alvarez, S. L., Rappenglueck, B., Mielke, L. H., Osthoff, H. D., and Stevens, P. S.: Measurements of hydroxyl and hydroperoxy radicals during CalNex-LA: Model comparisons and radical budgets, J. Geophys. Res.-Atmos., 121, 4211-4232, 2016.

Heard, D. E. and Pilling, M. J.: Measurement of $\mathrm{OH}$ and $\mathrm{HO}_{2}$ in the troposphere, Chem. Rev., 103, 5163-5198, 2003.

Hens, K., Novelli, A., Martinez, M., Auld, J., Axinte, R., Bohn, B., Fischer, H., Keronen, P., Kubistin, D., Nölscher, A. C., Oswald, R., Paasonen, P., Petäjä, T., Regelin, E., Sander, R., Sinha, V., Sipilä, M., Taraborrelli, D., Tatum Ernest, C., Williams, J., Lelieveld, J., and Harder, H.: Observation and modelling of $\mathrm{HO}_{\mathrm{x}}$ radicals in a boreal forest, Atmos. Chem. Phys., 14, 8723-8747, https://doi.org/10.5194/acp-14-8723-2014, 2014.

Hofzumahaus, A., Brauers, T., Aschmutat, U., Brandenburger, U., Dorn, H. P., Hausmann, M., Heßling, M., Holland, F., PlassDülmer, C., Sedlacek, M., Weber, M., and Ehhalt, D. H.: Reply to "Comment on "The measurement of tropospheric $\mathrm{OH}$ radicals by laser-induced fluorescence spectroscopy during the POPCORN field campaign" by Hofzumahaus et al. and "Intercomparison of tropospheric $\mathrm{OH}$ radical measurements by multiple folded longpath laser absorption and laser induced fluorescence" by Brauers et al.", Geophys. Res. Lett., 24, 3039-3040, 1997.

Holland, F., Hofzumahaus, A., Schäfer, J., Kraus, A., and Pätz, H.-W.: Measurements of $\mathrm{OH}$ and $\mathrm{HO}_{2}$ radical concentrations and photolysis frequencies during BERLIOZ, J. Geophys. Res.-Atmos., 108, 8246, https://doi.org/10.1029/2001JD001393, 2003.

Kanaya, Y., Sadanaga, Y., Hirokawa, J., Kajii, Y., and Akimoto, H.: Development of a Ground-Based LIF Instrument for Measuring HOx Radicals: Instrumentation and Calibrations, J. Atmos. Chem., 38, 73-110, 2001.

Kanaya, Y., Cao, R., Akimoto, H., Fukuda, M., Komazaki, Y., Yokouchi, Y., Koike, M., Tanimoto, H., Takegawa, N., and Kondo, Y.: Urban photochemistry in central Tokyo: 1. Observed and modeled $\mathrm{OH}$ and $\mathrm{HO}_{2}$ radical concentrations during the winter and summer of 2004, J. Geophys. Res.-Atmos., 112, D21312, https://doi.org/10.1029/2007JD008670, 2007a.

Kanaya, Y., Cao, R., Kato, S., Miyakawa, Y., Kajii, Y., Tanimoto, H., Yokouchi, Y., Mochida, M., Kawamura, K., and Akimoto, H.: Chemistry of $\mathrm{OH}$ and $\mathrm{HO}_{2}$ radicals observed at Rishiri Island, Japan, in September 2003: Missing daytime sink of $\mathrm{HO}_{2}$ and positive nighttime correlations with monoterpenes, J. Geophys. Res.-Atmos., 112, D11308, https://doi.org/10.1029/2006JD007987, 2007b.

Kanaya, Y., Hofzumahaus, A., Dorn, H.-P., Brauers, T., Fuchs, H., Holland, F., Rohrer, F., Bohn, B., Tillmann, R., Wegener, R., Wahner, A., Kajii, Y., Miyamoto, K., Nishida, S., Watanabe, K., Yoshino, A., Kubistin, D., Martinez, M., Rudolf, M., Harder, H., Berresheim, H., Elste, T., Plass-Dülmer, C., Stange, G., Kleffmann, J., Elshorbany, Y., and Schurath, U.: Comparisons of observed and modeled $\mathrm{OH}$ and $\mathrm{HO}_{2}$ concentrations during the ambient measurement period of the $\mathrm{HO}_{\mathrm{x}}$ Comp field campaign, Atmos. Chem. Phys., 12, 2567-2585, https://doi.org/10.5194/acp12-2567-2012, 2012.

Kim, S., Wolfe, G. M., Mauldin, L., Cantrell, C., Guenther, A., Karl, T., Turnipseed, A., Greenberg, J., Hall, S. R., Ullmann, K., Apel, E., Hornbrook, R., Kajii, Y., Nakashima, Y., Keutsch, F. N., DiGangi, J. P., Henry, S. B., Kaser, L., Schnitzhofer, R., Graus, M., Hansel, A., Zheng, W., and Flocke, F. F.: Evaluation of HOx sources and cycling using measurement-constrained model calculations in a 2-methyl-3-butene-2-ol (MBO) and monoterpene 
(MT) dominated ecosystem, Atmos. Chem. Phys., 13, 20312044, https://doi.org/10.5194/acp-13-2031-2013, 2013.

Klotz, B., Sørensen, S., Barnes, I., Becker, K. H., Etzkorn, T., Volkamer, R., Platt, U., Wirtz, K., and Martín-Reviejo, M.: Atmospheric Oxidation of Toluene in a Large-Volume Outdoor Photoreactor: In Situ Determination of Ring-Retaining Product Yields, J. Phys. Chem. A, 102, 10289-10299, 1998.

Konrad, S., Schmitz, T., Buers, H. J., Houben, N., Mannschreck, K., Mihelcic, D., Müsgen, P., Pätz, H. W., Holland, F., Hofzumahaus, A., Schäfer, H. J., Schröder, S., Volz-Thomas, A., Bächmann, K., Schlomski, S., Moortgat, G., and Großmann, D.: Hydrocarbon measurements at Pabstthum during the BERLIOZ campaign and modeling of free radicals, J. Geophys. Res., 108, 8251, https://doi.org/10.1029/2001JD000866, 2003.

Kubistin, D., Harder, H., Martinez, M., Rudolf, M., Sander, R., Bozem, H., Eerdekens, G., Fischer, H., Gurk, C., Klüpfel, T., Königstedt, R., Parchatka, U., Schiller, C. L., Stickler, A., Taraborrelli, D., Williams, J., and Lelieveld, J.: Hydroxyl radicals in the tropical troposphere over the Suriname rainforest: comparison of measurements with the box model MECCA, Atmos. Chem. Phys., 10, 9705-9728, https://doi.org/10.5194/acp10-9705-2010, 2010.

Lanzendorf, E. J., Hanisco, T. F., Donahue, N. M., and Wennberg, P. O.: Comment on: "The measurement of tropospheric $\mathrm{OH}$ radicals by laser-induced fluorescence spectroscopy during the POPCORN Field Campaign" by Hofzumahaus et al. and "Intercomparison of tropospheric $\mathrm{OH}$ radical measurements by multiple folded long-path laser absorption and laser induced fluorescence" by Brauers et al, Geophys. Res. Lett., 24, 3037-3038, 1997.

Levy, H.: Photochemistry of the lower troposphere, Planet. Space Sci., 20, 919-935, 1972.

Lu, K. D., Hofzumahaus, A., Holland, F., Bohn, B., Brauers, T., Fuchs, H., Hu, M., Häseler, R., Kita, K., Kondo, Y., Li, X., Lou, S. R., Oebel, A., Shao, M., Zeng, L. M., Wahner, A., Zhu, T., Zhang, Y. H., and Rohrer, F.: Missing OH s ource in a suburban environment near Beijing: observed and modelled $\mathrm{OH}$ and $\mathrm{HO}_{2}$ concentrations in summer 2006, Atmos. Chem. Phys., 13, 10571080, https://doi.org/10.5194/acp-13-1057-2013, 2013.

Mao, J., Ren, X., Zhang, L., Van Duin, D. M., Cohen, R. C., Park, J.-H., Goldstein, A. H., Paulot, F., Beaver, M. R., Crounse, J. D., Wennberg, P. O., DiGangi, J. P., Henry, S. B., Keutsch, F. N., Park, C., Schade, G. W., Wolfe, G. M., Thornton, J. A., and Brune, W. H.: Insights into hydroxyl measurements and atmospheric oxidation in a California forest, Atmos. Chem. Phys., 12, 8009-8020, https://doi.org/10.5194/acp-12-8009-2012, 2012.

Martinez, M., Harder, H., Kovacs, T. A., Simpas, J. B., Bassis, J., Lesher, R., Brune, W. H., Frost, G. J., Williams, E. J., Stroud, C. A., Jobson, B. T., Roberts, J. M., Hall, S. R., Shetter, R. E., Wert, B., Fried, A., Alicke, B., Stutz, J., Young, V. L., White, A. B., and Zamora, R. J.: $\mathrm{OH}$ and $\mathrm{HO}_{2}$ concentrations, sources, and loss rates during the Southern Oxidants Study in Nashville, Tennessee, summer 1999, J. Geophys. Res.-Atmos., 108, 4617, https://doi.org/10.1029/2003JD003551, 2003.

Michoud, V., Kukui, A., Camredon, M., Colomb, A., Borbon, A., Miet, K., Aumont, B., Beekmann, M., Durand-Jolibois, R., Perrier, S., Zapf, P., Siour, G., Ait-Helal, W., Locoge, N., Sauvage, S., Afif, C., Gros, V., Furger, M., Ancellet, G., and Doussin, J. F.: Radical budget analysis in a suburban European site dur- ing the MEGAPOLI summer field campaign, Atmos. Chem. Phys., 12, 11951-11974, https://doi.org/10.5194/acp-12-119512012, 2012.

Nehr, S., Bohn, B., Fuchs, H., Hofzumahaus, A., and Wahner, A.: $\mathrm{HO}_{2}$ formation from the $\mathrm{OH}+$ benzene reaction in the presence of $\mathrm{O}_{2}$, Phys. Chem. Chem. Phys., 13, 10699-10708, 2011.

Okabe, H.: Photochemistry of small molecules, John Wiley \& Sons, New York, 1978.

Ren, X., Harder, H., Martinez, M., Lesher, R. L., Oliger, A., Simpas, J. B., Brune, W. H., Schwab, J. J., Demerjian, K. L., He, Y., Zhou, X., and Gao, $\mathrm{H}$.: $\mathrm{OH}$ and $\mathrm{HO}_{2}$ Chemistry in the urban atmosphere of New York City, Atmos. Environ., 37, 3639-3651, 2003.

Ren, X., Brune, W., Cantrell, C., Edwards, G., Shirley, T., Metcalf, A., and Lesher, R.: Hydroxyl and Peroxy Radical Chemistry in a Rural Area of Central Pennsylvania: Observations and Model Comparisons, J. Atmos. Chem., 52, 231-257, 2005.

Ren, X., Brune, W. H., Oliger, A., Metcalf, A. R., Simpas, J. B., Shirley, T., Schwab, J. J., Bai, C., Roychowdhury, U., Li, Y., Cai, C., Demerjian, K. L., He, Y., Zhou, X., Gao, H., and Hou, J.: $\mathrm{OH}, \mathrm{HO}_{2}$, and $\mathrm{OH}$ reactivity during the PMTACSNY Whiteface Mountain 2002 campaign: Observations and model comparison, J. Geophys. Res.-Atmos., 111, D10S03, https://doi.org/10.1029/2005JD006126, 2006.

Ren, X., van Duin, D., Cazorla, M., Chen, S., Mao, J., Zhang, L., Brune, W. H., Flynn, J. H., Grossberg, N., Lefer, B. L., Rappenglück, B., Wong, K. W., Tsai, C., Stutz, J., Dibb, J. E., Thomas Jobson, B., Luke, W. T., and Kelley, P.: Atmospheric oxidation chemistry and ozone production: Results from SHARP 2009 in Houston, Texas, J. Geophys. Res.-Atmos., 118, 57705780, 2013.

Rohrer, F., Lu, K., Hofzumahaus, A., Bohn, B., Brauers, T., Chang, C.-C., Fuchs, H., Haseler, R., Holland, F., Hu, M., Kita, K., Kondo, Y., Li, X., Lou, S., Oebel, A., Shao, M., Zeng, L., Zhu, T., Zhang, Y., and Wahner, A.: Maximum efficiency in the hydroxylradical-based self-cleansing of the troposphere, Nat. Geosci., 7, 559-563, 2014.

Sanders, S. P., Friedl, R. R., Golden, D. M., Kurylo, M. J., Moortgat, G. K., Wine, P. H., Ravishankara, A. R., Kolb, C. E., Molina, M. J., Finlayson-Pitts, B. J., Huie, R. E., and Orkin, V. L.: Chemical Kinetics and photochemical data for use in atmospheric studies, Evaluation Number 15, JPL Publications 06-2, 2006.

Sheehy, P. M., Volkamer, R., Molina, L. T., and Molina, M. J.: Oxidative capacity of the Mexico City atmosphere - Part 2: $\mathrm{A} \mathrm{RO}_{\mathrm{x}}$ radical cycling perspective, Atmos. Chem. Phys., 10, 6993-7008, https://doi.org/10.5194/acp-10-6993-2010, 2010.

Shirley, T. R., Brune, W. H., Ren, X., Mao, J., Lesher, R., Cardenas, B., Volkamer, R., Molina, L. T., Molina, M. J., Lamb, B., Velasco, E., Jobson, T., and Alexander, M.: Atmospheric oxidation in the Mexico City Metropolitan Area (MCMA) during April 2003, Atmos. Chem. Phys., 6, 2753 2765, https://doi.org/10.5194/acp-6-2753-2006, 2006.

Stevens, P. S., Mather, J. H., and Brune, W. H.: Measurement of tropospheric $\mathrm{OH}$ and $\mathrm{HO}_{2}$ by laser-induced fluorescence at low pressure, J. Geophys. Res., 99, 3543-3557, 1994.

Stockwell, W. R., Kirchner, F., Kuhn, M., and Seefeld, S.: A new mechanism for regional atmospheric chemistry modeling, J. Geophys. Res.-Atmos., 102, 25847-25879, 1997. 
Tan, D., Faloona, I., Simpas, J. B., Brune, W., Shepson, P. B., Couch, T. L., Sumner, A. L., Carroll, M. A., Thornberry, T., Apel, E., Riemer, D., and Stockwell, W.: $\mathrm{HO}_{x}$ budgets in a deciduous forest: Results from the PROPHET summer 1998 campaign, J. Geophys. Res.-Atmos., 106, 24407-24427, 2001.

Tan, Z., Fuchs, H., Lu, K., Hofzumahaus, A., Bohn, B., Broch, S., Dong, H., Gomm, S., Häseler, R., He, L., Holland, F., Li, X., Liu, Y., Lu, S., Rohrer, F., Shao, M., Wang, B., Wang, M., Wu, Y., Zeng, L., Zhang, Y., Wahner, A., and Zhang, Y.: Radical chemistry at a rural site (Wangdu) in the North China Plain: observation and model calculations of $\mathrm{OH}, \mathrm{HO}_{2}$ and $\mathrm{RO}_{2}$ radicals, Atmos. Chem. Phys., 17, 663-690, https://doi.org/10.5194/acp17-663-2017, 2017.

Washenfelder, R. A., Young, C. J., Brown, S. S., Angevine, W. M., Atlas, E. L., Blake, D. R., Bon, D. M., Cubison, M. J., de Gouw, J. A., Dusanter, S., Flynn, J., Gilman, J. B., Graus, M., Griffith, S., Grossberg, N., Hayes, P. L., Jimenez, J. L., Kuster, W. C., Lefer, B. L., Pollack, I. B., Ryerson, T. B., Stark, H., Stevens, P. S., and Trainer, M. K.: The glyoxal budget and its contribution to organic aerosol for Los Angeles, California, during CalNex 2010, J. Geophys. Res.-Atmos., 116, D00V02, https://doi.org/10.1029/2011JD016314, 2011.
Whalley, L. K., Edwards, P. M., Furneaux, K. L., Goddard, A., Ingham, T., Evans, M. J., Stone, D., Hopkins, J. R., Jones, C. E., Karunaharan, A., Lee, J. D., Lewis, A. C., Monks, P. S., Moller, S. J., and Heard, D. E.: Quantifying the magnitude of a missing hydroxyl radical source in a tropical rainforest, Atmos. Chem. Phys., 11, 7223-7233, https://doi.org/10.5194/acp11-7223-2011, 2011.

Whalley, L. K., Blitz, M. A., Desservettaz, M., Seakins, P. W., and Heard, D. E.: Reporting the sensitivity of laser-induced fluorescence instruments used for $\mathrm{HO}_{2}$ detection to an interference from $\mathrm{RO}_{2}$ radicals and introducing a novel approach that enables $\mathrm{HO}_{2}$ and certain $\mathrm{RO}_{2}$ types to be selectively measured, Atmos. Meas. Tech., 6, 3425-3440, https://doi.org/10.5194/amt-6-3425-2013, 2013. 